\title{
A economia criativa no Brasil: o capitalismo cultural brasileiro contemporâneo ${ }^{1}$
}

\author{
Elder P. Maia Alves* \\ Carlos Alexsandro de Carvalho Souza*
}

Resumo: A reflexão que se segue tem como desiderato analisar a tradução e a institucionalização do tema/categoria de economia criativa no contexto políticoinstitucional brasileiro. Para tanto, elege dois agentes, um privado e outro público: a Federação das Indústrias do Estado do Rio de Janeiro (FIRJAN) e o Ministério da Cultura (MINC). Para compreender os usos teóricos e práticos que esses agentes tem feito do tema/conceito de economia criativa o trabalho alarga a bitola empírica, com vistas a evidenciar o feixe de processos que, de todos os lados, cruzam os mercados culturais brasileiros, dinamizando-os e tornando-os objetos dos mais diversos interesses estéticos e econômicos. Para nortear o exercício, o fio condutor da investigação é fornecido pelas especificidades e dinâmicas do consumo cultural das famílias brasileiras nos últimos dez anos.

Palavras-chave: economia criativa, consumo das famílias e mercado.

Abstract: The reflection that follows desideratum is to analyze the translation and institutionalization of the topic / category of creative economy in Brazilian political-institutional context. Therefore, elects two agents, one private and one public: the Federation of Industries of the State of Rio de Janeiro (FIRJAN) and the Ministry of Culture (MINC). To understand the theoretical and practical uses of these agents has made the theme / concept of the creative economy work extends the empirical gauge, in order to highlight the beam processes, from all sides, cross cultural Brazilian markets, boosting them and making them objects of various economic and aesthetic interests. To guide the exercise, the thread of research is provided by the specifics and dynamics of cultural consumption of Brazilian families in the past decade.

\footnotetext{
${ }^{1}$ A versão inicial deste trabalho foi apresentada na forma do plano de trabalho $A$ economia criativa no (do) Brasil, objeto da pesquisa de pós-doutoramento, realizada entre setembro de 2012 e fevereiro de 2013 no Instituto de Estudos Sociais e Políticos da Universidade do Estado do Rio de Janeiro (UERJ).

* Professor do Instituto de Ciências Sociais (ICS) e do Programa de Pós-Graduação em Sociologia da Universidade Federal de Alagoas (UFAL), membro do grupo de pesquisa Cultura, Memória e Desenvolvimento (CMD/Cnpq).

* Graduando de Ciências Sociais da Universidade Federal de Alagoas (ICS/UFAL), bolsista do Programa Institucional de Bolsas de Iniciação Científica (PIBIC). O trabalho apresentado derivou da pesquisa As indústrias da criatividade em Alagoas, que recebeu, em 2012, o prêmio de excelência acadêmica durante o IX Congresso Acadêmico da Universidade Federal de Alagoas (UFAL).
}

Latitude, vol. 6, n², pp.06-21, 2012

DOI: https://doi.org/10.28998/2179-5428.20120206 


\section{A economia criativa no Brasil: o capitalismo cultural brasileiro contemporâneo.}

Keywords: creative economy, household consumption and market.

\section{Introdução}

Em recente trabalho publicado², Gilles Lipovetsky e Jean Serroy buscam fundamentar aquilo que designam de cultura-mundo. Segundo os autores, a realidade global contemporânea está atravessada, de ponta a ponta, pela consecução da cultura-mundo, cuja dinâmica se estabelece a partir da expansão dos meios sociotécnicos de produção de imagens e sons; da ampliação e diferenciação das múltiplas formas de consumo simbólico-cultural; do volume de novos investimentos nos setores de turismo cultural e serviços de diversão e lazer; a abertura de novas corporações que exploram os segmentos de moda, arquitetura e design; dos negócios culturais espalhados pelo ciberespaço; da irreversível ampliação do mercado publicitário, que conjugados, sedimentam aquilo que os autores chamam de hipermodernidade ou capitalismo cultural. A cultura-mundo é, pois, uma categoria que busca apanhar a trama de formação planetária de um amálgama novo, profundamente intrincado, cuja face nos chega mais fugidia do que nunca, traduzida pelos autores por meio da categoria de hipercapitalismo ou cultura global de marcado.

As assertivas de Lepovetsky e Serroy, aliadas as descobertas de outros autores, concorrem para cristalizar a percepção acerca da interpenetração cada vez maior entre o domínio do simbólico e a esfera econômica, não mais como algo residual e secundário, mas como algo central às estratégias de ganho e expansão econômica de empresas, companhias de comunicação e grupos empresariais de diversos outros ramos da economia contemporânea de serviços, permitindo, assim, o uso da categoria de capitalismo cultural. Ainda de acordo com os autores, três vetores atestam o advento da cultura-mundo e a transformação do eixo de institucionalização e reprodução desse novo capitalismo. O primeiro diz respeito ao próprio significado econômico da produção e do consumo cultural, cuja envergadura alcança patamares impensáveis até pouco tempo, como nos Estados Unidos, por exemplo, onde recentemente a exportação das indústrias audiovisuais rende mais divisas do que as exportações aeronáuticas: "na época da globalização das indústrias do imaginário e do ciberespaço, a cultura é uma indústria, um complexo midiático-mercantil funcionando como um dos principais motores do crescimento das nações desenvolvidas" (LIPOVETSKY e SERROY). Como corolário, o segundo aspecto, de resto também já constatado por outros autores, concerne à criação de novos mercados culturais, derivados das novas formas de uso e consumo de serviços e produtos, cujo resultado consiste na diferenciação e especialização do consumo. Por fim, aliado aos aspectos anteriores, experimentase, segundo os autores, uma politização geral da produção cultural, cujos mercados

2 A cultura-mundo, Gilles Lipovetsky e Jean Serroy, São Paulo, Cia das Letras, 2011. 
Elder P. Maia Alves

Carlos Alexsandro de Carvalho Souza

e os fluxos de significados acionam, direta ou indiretamente, tensões e o acirramento das guerras das identidades e das memórias: “dão testemunho disso, em seu nível extremo e no cenário internacional, a multiplicação de massacres interétnicos, das guerras comunitárias, dos fanatismos etnoreligiosos e etnonacionalistas" (LIPOVETSKY e SERROY).

À luz dessas assertivas, o conceito e o tema da economia criativa pode ser pensado como uma consequência não programada e de longa duração sóciohistórica entre os diversos atravessamentos envolvendo o cultivo e a valorização da sensibilidade artístico-cultural e a racionalidade econômico-empresarial. Com efeito, a profusão e a aplicação do conceito/tema da economia criativa mundo a fora e, especialmente no Brasil, está escorada em um feixe de transformações: 1) o recrudescimento do processo de diferenciação do consumo simbólico-cultural; 2) a profusão de uma nova ecologia sócio-técnica, que têm coalhado o ambiente doméstico das famílias (miniaturização dos suportes e toda sorte de dispositivos digitais); 3) a instantaneidade das tecnologias da informação e da comunicação; 4) a valorização e legitimação das políticas culturais; 5) a utilização dos equipamentos culturais para o reordenamento e valorização econômica do espaço urbanoimobiliário; 6) o direcionamento de parte da nova racionalidade administrativa e empresarial para os negócios culturais; 7) o aumento das práticas de lazer e fruição no ambiente doméstico e fora dele; 8) o crescimento da proteção jurídica sobre a propriedade intelectual. Esse cipoal de processo concorreu para plasmar um amálgama contemporâneo ainda mais indissociável entre o domínio estéticoexpressivo e o domínio econômico-comercial. No entanto, as consequências práticas dessas transformações têm elevado o poder e os investimentos em torno do primeiro, projetando sobre o segundo novas práticas e valores. O tema/conceito da economia criativa é um corolário desse direcionamento e dessa inflexão, e tem, por conseguinte, contribuído para deslocar a balança de poder em direção ao primeiro domínio.

Os processos apontados acima concorreram para transformar, paulatinamente, os códigos ético-estéticos e o fazer artístico-cultural, produzindo uma nova hierarquia artístico-cultural e a mudança substancial no estatuto social da criatividade. Esse movimento levou, desde os anos 80, a uma aproximação entre arte, tecnologia e entretenimento. Foi exatamente essa aproximação que permitiu a advento de conceito de economia criativa e toda a sua família conceitual: indústrias criativas, classes criativas, cidades criativas, capital criativo, territórios criativos, distritos criativos e profissionais criativos. Por sua vez, os processos de transmidiação, convergência e digitalização do simbólico constitui a ossatura desse movimento, que permitiu, a um só tempo, aproximar arte, tecnologia e entretenimento dos antigos negócios e mercados culturais, como o cinematográfico, o publicitário, o televisivo e o editorial. Esses enquadramentos amplos impactaram no modo como os empresários, os executivos, as empresas, as corporações, os governos, as 


\section{A economia criativa no Brasil: o capitalismo cultural brasileiro contemporâneo.}

organizações não governamentais e as instituições transnacionais passaram a olhar para as relações entre cultura e economia. Em face desse aspecto, a pergunta que norteia a segunda parte deste trabalho é a seguinte: em que medida a inserção e a legitimação da categoria/tema de economia criativa tem dilatado os contornos do capitalismo cultural brasileiro contemporâneo?

O novo léxico que envolve as relações entre economia e cultura, no Brasil, vem sendo dinamizado e potencializado por três agentes principais: o Ministério da Cultura, por meio da Secretaria da Economia Criativa (SEC); a Federação das Indústrias do Estado do Rio de Janeiro (FIRJAN) e o Serviço de Apoio a Micro e Pequenas Empresas (SEBRAE). Essas agentes têm filtrado o conceito de economia criativa à luz das suas perspectivas institucionais e interesses econômico-culturais. As ações, pesquisas, propostas, projetos e políticas implementadas e difundidas por tais agentes concorrem, direta ou indiretamente, para a formação de uma justaposição e uma total imbricação entre criatividade e diversidade. Essa relação aparece, nas ações institucionais desses agentes, como uma reciprocidade permanente, que aponta para a cultura popular brasileira (também filtrada e valorizada por meio das políticas para o patrimônio imaterial) como a fonte viva e vibrante da diversidade artístico-cultural brasileira e, por conseguinte, como o grande manancial criativo, que pode ser explorado, seja por meio de bens, serviços ou atividades culturais. Essa rede de relações figura como uma justificativa éticoestética presente em diversas falas, ações e projetos, desde estilistas e designers, passado por cineastas e publicitários até empresário do entretenimento e do turismo, alcançando gestores culturais, técnicos e políticos. Para um agente especifico como o Ministério da Cultura, essa de justificação passa por dois outros princípios: inclusão social e sustentabilidade.

Desse modo, tanto o Ministério da Cultura (MINC) quanto os demais agentes mencionados deslocam e atualizam o tema das relações entre economia e cultura a partir de determinados valores e interesses político-institucionais, explorando, por exemplo, a chave contemporânea do desenvolvimento humano sustentável, aproximado a diversidade simbólico-cultural da diversidade ecológicoambiental, ambas vistas como imprescindíveis. Em outra frente, essa mesma rede de justificação é atualizada e utilizada por meio do debate contemporâneo entre cultura e desenvolvimento, que tem ocupado a atenção e os interesses de importantes setores governamentais, de segmentos da sociedade civil e das agencias transnacionais. Em face de tais aspectos e processos, torna-se imperioso indagar: por que ante as diversas criatividades contemporâneas (tecnológica, econômica, etc.), a criatividade artístico-cultural é a mais valorizada e percebida (pelos novos agentes econômico-culturais) como o grande insumo econômico contemporâneo? Por que setores, meios, suportes e linguagens vistos, até pouco tempo, como pouco criativos ou mesmo anticriativos figuram hoje como representantes incontestes da economia criativa? Por que e como as antigas indústrias 
Elder P. Maia Alves

Carlos Alexsandro de Carvalho Souza

culturais (televisão, rádio, publicidade, mercado editorial, etc.) tornaram-se indústrias criativas, inscritas no núcleo pulsante da economia criativa?

\section{A economia criativa no Brasil: as linhas de força de uma categoria nativa - usos, traduções e acomodações (a tessitura do capitalismo cultural).}

Na Avenida Cológeras (situada no centro da cidade do Rio de Janeiro e palco de muitos encontros criativos, como aquele ocorrido entre as duplas de compositores Luiz Gonzaga/Humberto Teixeira e Tom Jobim/Vinicius de Moraes nos anos 40 e $50^{3}$ ), ladeada pela Rua Santa Luzia e contígua a Avenida Graça Aranha, situa-se, hoje, dois dos cinco principais agentes político-institucionais que têm traduzido, difundido e legitimado o conceito e o tema da economia criativa no Brasil: a Federação das Indústrias do Estado do Rio de Janeiro (FIRJAN) e o Serviço de Apoio à Micro e Pequena Empresa (SEBREA RJ). Essas instituições, movidas por interesses político-institucionais específicos, têm dinamizado e implementado ações, projetos e políticas inspiradas e justificadas a partir do conceito de economia criativa e de todo o temário que esta mobiliza. O perímetro urbano aludido, que envolve duas frementes avenidas e uma rua não menos movimentada, mudou muito entre as décadas de 40 e 50 do século XX e a segunda década do século XXI, sobretudo em razão dos investimentos imobiliários corporativos e da construção da estação do metrô da Cinelândia ${ }^{4}$, por onde milhares de pessoas, todos os dias, acessam a Rua Santa Luzia em direção as Avenidas Calógeras e Graça Aranha, entre outras do pulsante centro da cidade. O que também mudou, em pouco mais de 60 anos, foi a relevância econômica dos bens, serviços e atividades simbólicoculturais para a economia contemporânea de serviços da cidade do Rio de Janeiro e do Brasil. Logo, se alterou também, de modo substantivo, a forma de olhar para as relações entre a produção cultural e os diversos negócios, inclusive aqueles considerados não propriamente negócios culturais. Em uma palavra: as atividades artístico-culturais deixaram de ser apenas uma ocupação e um vetor de atuação das empresas de comunicação e cultura, mas uma atividade que interessa também às corporações industriais, as empresas multinacionais e as diferentes organizações governamentais. Alteraram-se significativamente os elos relacionais envolvendo arte, técnica e mercado e, por conseguinte, os modos de se interpretar, intervir, planejar e legitimar esses feixes de relações. O mesmo perímetro urbano serve, pois, de emblema para justapor o cruzamento de ruas e avenidas e o cruzamento de planos histórico-empíricos distintos.

\footnotetext{
${ }^{3}$ Verificar o trabalho A economia criativa do Brasil: criação, mercado e modernização cultural, publicado neste dossiê.

${ }^{4}$ A estação de metrô da Cinelândia foi inaugurada em 1979.
} 


\section{A economia criativa no Brasil: o capitalismo cultural brasileiro contemporâneo.}

Para compreender o processo de profusão e legitimação do tema e da categoria de economia criativa e, por conseguinte, as suas implicações econômicas e práticas é necessário tratar o tema/categoria como uma formulação nativa. Essa visada metodológica permite enxergar com clareza os usos teórico-práticos do conceito/tema de economia criativa, assim como os distintos interesses políticoinstitucionais que se acomodam e se formam em torno do tema da economia criativa. Urdida a partir dos trânsitos relacionais entre as escolas de negócios (notadamente europeias), os governos nacionais (principalmente o governo do Reino Unido e o governo australiano) e as agências transnacionais (como a UNESCO e a UNCTAD), no decurso das duas últimas décadas, a categoria de economia criativa é uma síntese teórica nativa, utilizada por uma miríade de novos agentes econômico-culturais para justificar e implementar políticas econômico-culturais e, por conseguinte, a criação de novos negócios culturais. Com efeito, importa tomar o conceito não como uma categoria analítica (forjada pelo artesanato intelectual das ciências sociais), mas como um conceito (um meta-discurso) mobilizado por diversos agentes econômico-culturais para justificar ações e legitimar novas visadas, assim como para ampliar o escopo dos mercados culturais. Em outros termos, importa muito mais os usos práticos do conceito e as suas implicações político-econômicas e muito menos o eventual potencial explicativo e interpretativo do mesmo. Nesse sentido, é significativamente mais fecundo compreender como os investimentos normativos, econômicos, políticos e culturais em torno da criatividade e dos processos criativos têm alterado o estatuto social da criatividade e produzido uma nova hierarquia artístico-cultural no Brasil.

Nesses termos, sustentamos que a categoria de economia criativa é uma construção simbólico-discursiva, erigida em meio às transformações econômicoculturais das últimas duas décadas. Seu núcleo de significado consiste em revelar, por um lado, a plêiade de atividades e realizações artístico-culturais contidas em uma série de bens e serviços, por outro, opera como registro discursivo capaz de engendrar novas práticas e fundos de saber considerados eminentemente criativos. Com feito, em uma frente, a categoria de economia criativa emerge como um desdobramento simbólico-conceitual de processos em curso desde meados do século passado, situando-se dentro de um novo regime discursivo acerca da esfera cultural, vicejando um agudo discurso culturalista no ambiente empresarialcorporativo e governamental; em outra frente, a categoria de economia criativa passa a ser, ela mesma, instauradora de novas realidades e dinâmicas econômicoculturais, pois é um categorias I tema que tem sido assaz utilizada para justificar e executar políticas culturais em países como o Brasil.

O conceito de economia criativa é resultado de uma ampliação na categoria de indústrias criativas. Este último apareceu pela primeira vez no mundo econômico em uma publicação da revista Businness Week, intitulada The Creative Economy - the 21 century corporation. No entanto, no mundo acadêmico o conceito surge um ano 
antes, no livro Creative industries: contracta between art and commerce, publicado em 2000, por Ricard Caves, professor de economia da Universidade de Harvard. No decurso da década passada os termos passaram a ganhar popularidade e, cerca de dez anos após a publicação do relatório da UNESCO e de discussões na Europa, os conceitos passaram a fazer parte de plataformas governamentais, das justificativas de políticas culturais e de relatórios de gestão. No manifesto pré-eleitoral da campanha política de 1997 para o parlamento inglês, nota-se a importância conferida pelo New Labor (novo Partido Trabalhista inglês) ao conceito de economia criativa, que recebe um destaque concretizado no decurso das gestões do primeiro ministro Tony Blair. Logo no primeiro ano do governo Blair, foi criado o grupo de trabalho Creative Inustries Task Force, ligado ao Department for Culture, Media and Sports (DCMS), do governo Inglês. Percebe-se, progressivamente, como a partir do fim dos anos noventa o conceito de indústrias criativas vai se avizinhando de outros mais largos ou correlatos, como economia criativa e cidades criativas. Ressalta SantosDuisenberg:

De qualquer forma, as indústrias criativas estão no coração da economia criativa. Para a Unctad, elas estão centradas nas artes e na cultura, mas não estão restritas a elas. Podem ser produtos tangíveis ou serviços intangíveis com conteúdo criativo, valor econômico e objetivos de mercado. As indústrias criativas podem ser definidas como o ciclo de criação, produção, distribuição de produtos ou serviços comercializáveis, que usam a criatividade como insumo principal (SANTOS-DUISENBERG, 2008).

De acordo com o governo inglês, as indústrias criativas correspondem aos setores que tem origem na criatividade, que possuem potencial para criação de riqueza e emprego através da exploração da capacidade intelectual, essa definição abarca setores como a arquitetura, o mercado de artes e antiguidades, artesanato, design, moda, filmagem, softwares interativos, músicas, artes performáticas, editoração, serviços de computação, rádio e televisão. Segundo o documento publicado pelo governo inglês em 2001 (Creative Industries Mapping Document 2001), no Reino Unido as indústrias criativas obtiveram uma receita anual geral de 112 bilhões de libras esterlinas, empregando aproximadamente 1,3 milhões de trabalhadores, calcula-se que esse montante correspondeu, àquela altura, a $6 \%$ da população economicamente ativa, correspondendo a $5 \%$ do total do Produto Interno Bruto (PIB). Os números são bastante eloquentes, alcançando relevância análoga em outros países europeus, como Holanda e Alemanha, além de Índia e China.

Como se pode notar, o conceito e toda a sua rede de categorias associadas ganharam profusão e densidade político-institucional a partir da tríade relacional entre as escolas de negócios europeias e norte-americanas (cursos de graduação e pós-graduação de economia, administração, comunicação, direito e marketing), os interesses governamentais e a atuação político-normativa das agências 


\section{A economia criativa no Brasil: o capitalismo cultural brasileiro contemporâneo.}

transnacionais, como a UNCTAD e a UNESCO. Não por acaso, os principais formuladores do conceito (que também são os maiores defensores do tema), como Ricard Caves, Richard Flórida e Jonh Howkins, vem das escolas de administração e negócios aplicados. Os trabalhos desses autores serviram de subsídios práticos para a realização de pesquisas globais e projetos de persuasão e legitimação do tema e dos conceitos pertencentes à família da economia criativa. Em 2008, por exemplo, a UNCTAD publicou um extenso relatório ${ }^{5}$, resultado de uma pesquisa desenvolvida entre 2005 e 2006, acerca das indústrias criativas, apontando números bem eloquentes, mas, sobretudo, dilatando o significado das atividades classificadas como criativas. A definição cunhada pela UNCTAD, diferente do estudo precedente empreendido pela instituição, que se limitava aos setores artístico-culturais, abarca todos os bens e serviços que usam a criatividade como e os recursos intelectuais como insumos primários e imprescindíveis. De acordo com o estudo, entre 2000 e 2005, o volume comercial de bens e serviços criativos alcançou um crescimento anual de $8,7 \%$, sendo que a economia criativa europeia empregava, em 2003, 5,6 milhões de trabalhadores e produzia um volume de S\$ 654 bilhões, crescendo acima dos demais setores da economia europeia.

De acordo com a UNCTAD, a economia criativa está dividida em quatro categorias amplas (patrimônio cultural; artes; mídias e serviços funcionais), no interior das quais existem oito subcategorias, respectivamente: artesanato; expressão cultural tradicional, festivais e celebrações; artes visuais, pintura, escultura, fotografia, música, teatro, dança, opera, marionete, circo, etc.; edição e mídia impressa, livros, imprensa, outras publicações, cinema, difusão televisão e rádio; design de moda, de interiores, gráfico, de jóias, novas mídias, conteúdo digital, software, jogos, animação, arquitetura, propaganda, P \& D e serviços culturais. Ainda de acordo com a UNCTAD, as economias desenvolvidas exportam 58\% de todos os produtos criativos (excluindo-se a quarta grande categoria, os serviços funcionais), sendo as economias em desenvolvimento responsáveis por $41 \%$ desses produtos, e as economias em transição por $1 \%$. O produto mais exportado é o design $(65 \%)$, seguido da edição $(13 \%)$, o artesanato $(7 \%)$, as artes visuais também $7 \%$, as novas mídias (4\%), a música (4\%). Não são computados, por exemplo, os serviços, como shows, festas populares e eventos esportivos, devido a dificuldade de mensuração. Mediante esses dados e o relatório publicado, a agência de tornou a principal liderança técnica e política envolvendo o debate a cerca da economia criativa em âmbito transnacional. Chama atenção no desenho operacional do modelo UNCTAD ausência de uma hierarquia da criatividade artístico-cultural, como foi bastante comum até os anos 90 do século passado. Assim, o teatro, a opera, o artesanato e a dança figuram no interior

\footnotetext{
${ }^{5}$ Creative Economy - Report 2008, United Nations, 2008.
} 
das indústrias criativas e da economia criativa tanto quanto a publicidade, o design e a televisão.

Chama atenção, ainda, no tratamento teórico e prático do tema da economia criativa por parte da UNCTAD a aproximação com o tema das indústrias culturais. $\mathrm{Na}$ grande maioria dos documentos formulados pela instituição os termos se justapõem e se fundem. No caso especifico da UNCTAD o acento crítico da categoria de indústria cultural vem sendo esvaziado. Em linhas gerais, o conceito de indústria cultural - tão disseminado entre as vanguardas político-culturais da esquerda latino-americana e de outras partes do mundo a partir da década de 60 do século XX -, cunhado, em parte, para denunciar a "conspurcação" da arte pela indústria, passou a ser deslocado e esvaziado em nome de novas formas de conceituação e classificação, logo tornadas dispositivos de justificação e implementação de políticas de planejamento cultural. O cerne da mudança consistiu na maneira de se reputar e se definir a criatividade, enfatizando alguns aspectos e mitigando outros, conformando uma espécie de hierarquia da criatividade contemporânea, que, no ambiente da UNCTAD, é muito mais simétrica, acomodando antigas tensões e antinomias. Ao que tudo indica, vê-se, hoje, uma valorização contumaz da criatividade, atribuída aos próprios produtos da indústria cultural global. Não que o conceito de indústria cultural tenha perdido inteiramente seu aspecto crítico-normativo, mas que a dimensão da criatividade inscrita nos bens e serviços da indústria cultural passou a ser valorizada. Passou-se, por assim dizer, de uma crítica feroz e combativa da indústria cultural, para uma celebração e valorização das indústrias da criatividade. É possível sugerir que houve uma espécie de limpeza semântica. $\mathrm{O}$ que antes era identificado como algo eminentemente uniformizador, padronizador e concentrador a partir dos anos 90 passou a ser associado, cada vez mais, à criatividade e à diversidade. Essa mudança não ocorreu como um ato repentino. A rigor, a família conceitual encabeçada pelo conceito/tema de economia criativa expressa o aparecimento e o funcionamento de novos códigos ético-estéticos, menos informados por uma crítica político-cultural aos meios, aos seus suportes e as suas linguagens (televisão, cinema, rádio, livro, publicidade, moda, design, arquitetura, entre outros) e mais comprometida com a criação de valor simbólico-econômico a partir da quase fusão entre a sensibilidade estético-expressiva e a racionalidade econômico-comercial, escorada na noção de setores e/ou núcleos criativos (audiovisual; expressões culturais; patrimônio; criações funcionais; entretenimento; gastronomia, tecnologia, etc.). Esses novos códigos ético-estéticos estão espraiados por um conjunto de agentes, alguns antes exclusivamente econômicos, mas que agora exercem um significativo poder simbólico no âmbito das relações entre arte, técnica e mercado. Um exemplo claro a esse respeito é a definição e a comparação entre indústria cultural e indústria criativa cunhada pelo DCMS (Departamento de Cultura, Mídia e Esporte do Governo 


\section{A economia criativa no Brasil: o capitalismo cultural brasileiro contemporâneo.}

Inglês, a quem cabe formular e implementar as políticas para economia criativa na Inglaterra):

As "indústrias criativas" são analiticamente primas-irmãs das indústrias culturais; diferentes mas obviamente da mesma família ou atividade. O que elas produzem tem alto grau de valor simbólico e funcional. Arquitetura, design, moda, serviços de computação e propaganda são tipicamente setores criativos, que no mercado têm de passar pelos testes da cultura e funcionalidade. Anúncios têm de vender produtos, mas funcionam melhor quando expressam firmemente a cultura. Edifícios devem ser tanto esteticamente agradáveis como funcionais. Design deve incorporar cultura, mas é inútil se os produtos não funcionam direito. Roupas devem ser culturalmente de vanguarda mas ao mesmo tempo trajáveis. Nem todo edifício roupa, anuncio ou peça de design passa por ambos os testes, mas as indústrias criativas são mais saudáveis e vitais quando o maior número possível deles passa. (DCMS, 2007, apud REIS, 2012, p.43).

As homologias entre indústria cultural e indústria criativa verificada no documento do DCMS se devem a dois fatores. Primeiro, a categoria de indústria cultural não teve na Inglaterra o mesmo apelo critico-normativo que experimentou no Brasil e na América Latina. O conceito de cultura popular entre as elites políticas e culturais inglesas, desde os anos 50 e 60, se equivale ao conceito de cultura de massa, produzido e consumido via os meios de comunicação modernos: televisão, rádio e cinema. Portanto, como o processo de industrialização e urbanização das principais cidades inglesas remonta ao século XIX, as reminiscências e expressões populares do mundo rural (matriz do conceito de cultura popular em outras partes da Europa e na América Latina) não logrou a mesma importância política e estética que teve em outras latitudes. Segundo, as transformações ocorridas nos códigos ético-estéticos das elites culturais e políticas europeias, desde os anos 80, aproximaram e mitigaram eventuais incongruências entre a criatividade artísticocultural, as mediações técnicas e os interesses econômicos da chamada indústria cultural. Não deixa de ser significativo o fato do texto do DMCS falar em indústrias culturais, no plural, atribuindo um sentido mais diversificado, menos concentrador e uniformizador àquele imputado pelos teóricos da Escola de Frankfurt. Para uma organização como a UNCTAD, que busca dinamizar e intensificar os fluxos e as trocas comerciais, importa menos estabelecer distinções e erguer uma hierarquia 
da criatividade e muito mais promover uma ampla inclusão dos segmentos, linguagem e setores, genericamente identificados como criativos. Segundo as estimativas da própria UNCTAD, economia criativa representará, em 2013, entre 7\% e $10 \%$ do PIB global, apontando para um crescimento ainda maior por volta de 2020 , cerca de $20 \%$ do PIB mundial. A organização norteia-se, assim, muito mais pelas perspectivas de crescimento e dinamização do comércio criativo global, visto como instrumento de promoção do desenvolvimento e do bem estar, e muito menos por um critério artístico tributário das tradições e linguagens estéticas. Exatamente por isso, há por parte dos países membros e da própria UNCTAD, diversos investimentos políticos e jurídicos em torno da propriedade intelectual, notadamente do direito autoral, das patentes e das marcas. A coordenadora do primeiro relatório mundial sobre economia criativa (Criative Economy Report, UNCTAD, 2008), Edna Dos Santos-Duisenberg, ressalta: “digno de nota é que a designação "indústrias criativas" ampliou a amplitude das indústrias culturais, transcendendo as artes, e marcou uma mudança na abordagem das atividades comerciais em potencial, que até recentemente eram consideradas predominantemente em termos não-econômicos". Os relatórios, seminários, projetos e pesquisas realizados pela UNCTAD e outros agentes transnacionais, estão sendo traduzidos no contexto político-institucional brasileiro, sobretudo, pelo Ministério da Cultura (MINC), a FIRJAN e o SEBRAE.

Gráfico 1. Coleta de notícias nos sítios especializados acerca da economia criativa: ago/2012-jan/2013.

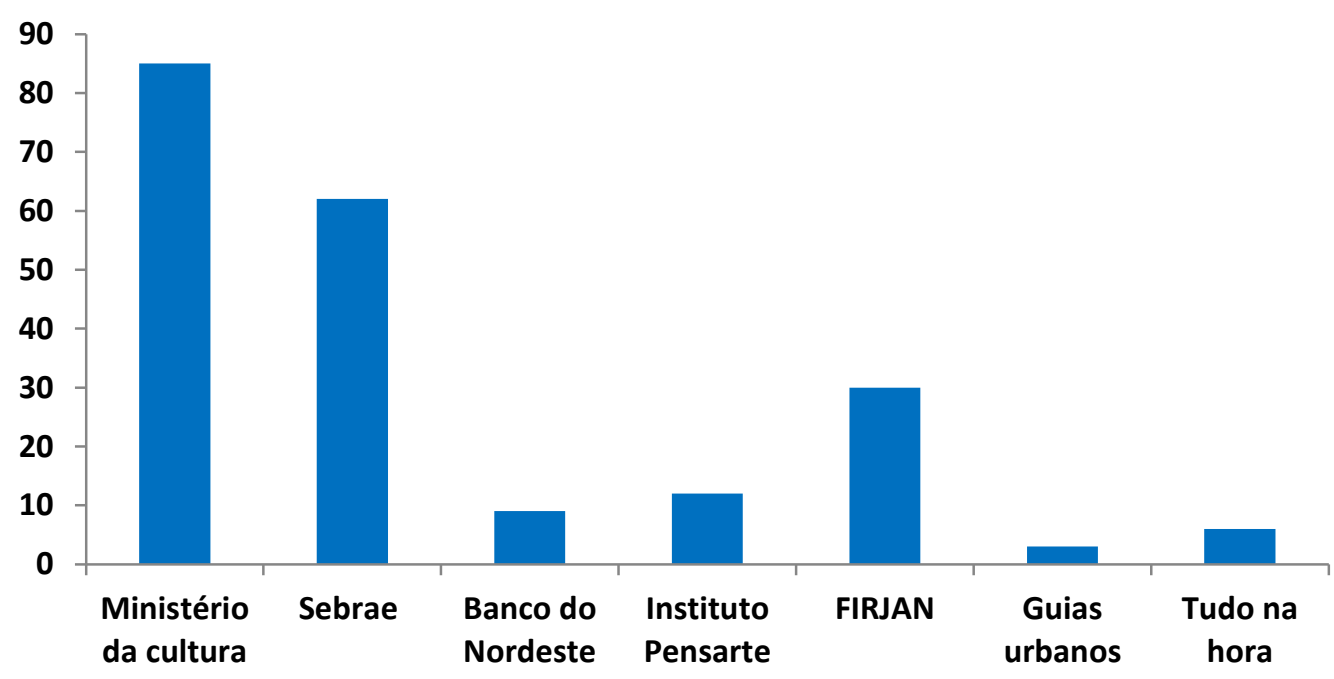

Fonte: o autor. 


\section{A economia criativa no Brasil: o capitalismo cultural brasileiro contemporâneo.}

Bastante inspirada e impactada pelos dados e o modelo difundido pela UNCTAD, em 2008, o Sistema FIRJAN (composto pela Federação das Indústrias do Estado do Rio de Janeiro - Firjan; Centro Industrial do Rio de Janeiro - CIRJ; Serviço Social da Indústria - SESI; Serviço Nacional de Aprendizagem Industrial SENAI; e Instituto Edivaldo Lodi - IEL), no âmbito do Programa Rio Criativo: nossa arte, nossa indústria, publicou o trabalho A cadeia da indústria criativa no Brasil, através da publicação número 2 do periódico Estudos Para o Desenvolvimento do Estado do Rio de Janeiro. A publicação, disponível no sitio da organização, traz um panorama minucioso acerca das indústrias criativas brasileiras, notadamente as indústrias criativas fluminenses. A publicação apresenta dados que acentuam tendências e revelam novas descobertas. Logo no inicio da publicação, o Sistema FIRJAN destaca que as indústrias criativas já vem sendo tratada pela organização como um dos segmentos ancora do Estado, ou seja, como um dos vetores mais relevantes para o desenvolvimento do Rio de Janeiro. Desse modo, alerta o trabalho, para que se explicita tal relevância o estudo conduzido (desenvolvido ao longo do ano de 2006) buscou dividir as indústrias da criatividade em uma cadeia interdependente, preenchida por 1) núcleo, composto por doze setores líderes; 2) as atividades relacionadas, composta por segmentos que fornecem serviços e bens ao núcleo; 3) as atividades de apoio, que ofertam e fazem circular, direta ou indiretamente, os bens e serviços. Diante desse encadeamento, o estudo evidenciou que o núcleo, em 2006, mantinha 638 mil trabalhadores no país, o que correspondia a 1,8\% de todo o trabalho formal, sendo que no Estado do Rio de Janeiro esse percentual sobe para 2,4\% (cerca de 82 mil trabalhadores formais), o maior percentual do pais.

No total, a cadeia da indústria criativa (núcleo, atividades relacionadas e atividades de apoio) correspondia, em 2006, a 21,8\% dos trabalhadores formais do país, ou seja, 7,6 milhões de pessoas. Seguindo uma regularidade nacional, os trabalhadores do núcleo da cadeia da indústria criativa auferem uma renda superior à média nacional, $R \$ 1.666$, ao passo que a média nacional era de $R \$ 1170$, ou seja, $42 \%$ acima da média nacional; sendo que no Rio de janeiro a média dos ganhos fluminenses é de $R \$ 1.330$, ao passo que os trabalhadores do núcleo obtêm $R$ \$ 2.182 , cerca de $64 \%$ acima da média do estado. Segundo a publicação, a cadeia da indústria criativa no Brasil, em 2006, corresponda a cerca de 16,4\% do total do PIB brasileiro, aproximadamente $\mathrm{R} \$ 381$ bilhões, sendo que o núcleo responde por 2,6\%; as atividades relacionadas, $5,4 \%$; e as atividades de apoio, $8,4 \%$; sendo que, no Estado do Rio de Janeiro, toda a cadeia produtiva da industria criativa corresponde a $17,8 \%$ do PIB estadual, cujo núcleo responde por 4,0\% (FIRJAN, 2008). De acordo com a publicação, que colheu subsídios junto à nova Classificação Nacional das Atividades Econômicas (CNAElIBGE 2007), o núcleo da cadeia da indústria da criatividade, além dos doze setores, abriga 42 atividades; o elo 
atividades relacionadas abarca 68 atividades e, por fim, o elo de apoio, envolve o total de 48 atividades.

O estudo da FIRJAN se tornou pioneiro e decisivo, não porque apresente um novo olhar para as relações entre o domínio estético-expressivo e o domínio econômico-comercial, mas porque a entidade passou a ser a matriz de dados de todos aqueles que, direta ou indiretamente, passaram a se interessar pelo tema. Note-se que a base de dados não é acessada junto a nenhuma universidade pública ou instituto de pesquisa (IBGE ou IPEA, por exemplo), mas a uma entidade privada, que representa os interesses e o planejamento dos diversos segmentos industriais do Estado do Rio de Janeiro. Em 2012 o estudo foi atualizado, incorporando novos temas, como os dados acerca das empresas criativas e a estrutura da mão de obra dos profissionais criativos, além da participação dos segmentos do núcleo criativo em cada um dos 26 estados da federação. O modelo inseriu, ainda, mais dois núcleos criativos: pesquisa e desenvolvimento e biotecnologia. Não por acaso setores imputados como bastante criativos e dinâmicos, por autores como Florida e Howkins. Os núcleos criativos do estudoguia passaram, assim, de 12 para 14. Segundo os novos dados, havia $143 \mathrm{mil}$ empresas atuando no núcleo criativo, produzindo recursos da ordem de $\mathrm{R} \$ 110$ bilhões de reais (cerca de 2,7\% do PIB brasileiro); abarcando cerca de $810 \mathrm{mil}$ profissionais (crescimento de cerca de 30\% em comparação a 2006), cerca de 1,7\% dos trabalhadores do país. Quanto à remuneração média, os trabalhadores das indústrias criativas recebem cerca de três vezes mais do que os demais trabalhadores, obtendo uma média salarial de $R \$ 4.693$, ao passo que os demais obtiveram uma média de $\mathrm{R} \$ 1.733$. 


\section{A economia criativa no Brasil: o capitalismo cultural brasileiro contemporâneo.}

Figura 1. A cadeia da indústria criativa no Brasil, 2012.

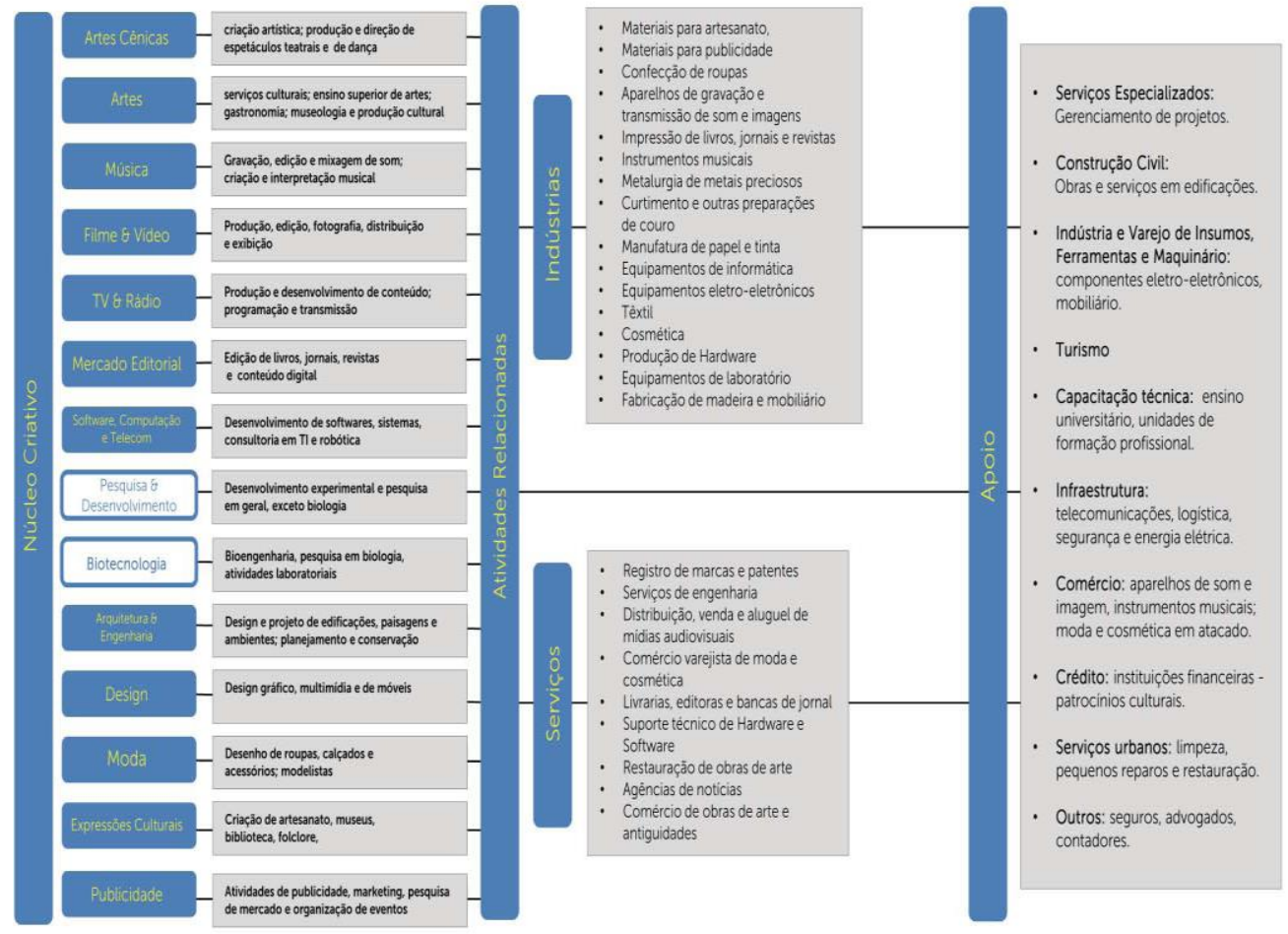

Fonte: SISTEMA FIRJAN

É preciso situar sua atuação em face dos interesses e motivações que guiaram o Sistema FIRJAN na realização da pesquisa-guia e na promoção desse tema em particular. Os termos, as classificações e parte da justificativa do estudo realizado pela FIRJAN são bem próximos dos adotados pela UNCTADIONU e o governo inglês ao longo da última década. Nesse caso específico, o Sistema FIRJAN - um poderoso agente econômico que envolve entidades ligadas à esfera produtivo-econômica brasileira - interessa-se pelo tema em razão das oportunidades econômicas locais e nacionais que o tema pode trazer, assim como dos dividendos políticos que o mesmo pode vicejar junto a setores da sociedade civil. Para tanto, a organização produziu um estudo contundente e revelador, valioso em si para aqueles que se ocupam do fenômeno, mas também decisivo para a atividade-fim do sistema, qual seja, assessorar o conjunto das empresas e corporações do Estado do Rio de Janeiro nas suas estratégias de ganho e crescimento econômico, ou, como anuncia o lema do sistema: "informar, formar e transformar: informa, forma, transforma". O temalcategoria das indústrias criativas leconomia criativa permite, a partir dos agentes que compõem o Sistem FIRJAN, informar (como é o caso da supracitada pesquisa), formar (desenvolver mecanismos de atuação: cursos, treinamentos, seminários, palestras) e transformar 
(criando empresas e os fundos de saberes criativos necessários à produção e circulação dos bens e serviços simbólico-culturais). Esse encadeamento de ações institucionais irá ser certamente condensado, no âmbito das indústrias criativas, por ocasião do funcionamento da Casa Firjan das Indústrias Criativas, que, de acordo com a gerente Cristiane Alves ${ }^{6}$, passará a funcional na Zona Sul da cidade do Rio de Janeiro, no Bairro de Botafogo, a partir de 2014.

Com efeito, desde 2006, a FIRJAN passou a se interessar pelo tema das indústrias criativas devido à gigantesca profusão dos negócios culturais no Estado do Rio de Janeiro e às reais possibilidades de deslocamento das atividades artístico-culturais do interior do ambiente propriamente industrial. Por isso, o estudo da federação não estabelece como critério a separação a partir das peculiaridades das linguagens estético-artísticas (filme, música, dança, escultura, arquitetura, pintura, etc.), mas sim núcleos criativos, que acionam e acomodam diversos setores no interior de uma cadeia produtiva ou uma rede geral de produção de valor simbólico-econômico. Diante dessa cadeia, a entidade pode, a partir dos seus membros e sócios, distinguir as potencialidades e fragilidades, induzir demandas e estudos, legitimar ações e profissionalizar setores, prospectando e escavando os melhores ambientes de negócios. Por outro lado, pode, ainda, liderar o processo de construção de uma agenda mais ampla, que envolve a justaposição das atividades industriais com o conjunto dos fazeres artístico-culturais, redirecionando o lugar político-institucional da cultura no ambiente empresarial-corporativo brasileiro.

Seria tentador explorar o crescimento dos mercados culturais no Brasil nos últimos dez últimos anos a partir do emaranhado de relações envolvendo os três elos fundamentais definidos no consagrado estudo da FIRJAN: núcleo criativo; atividades relacionadas e apoio. Fazê-lo seria, agora sim, passar do modelo da realidade para a realidade do modelo. O desenho empírico cunhado pela FIRJAN serve muito mais para compreender os usos e as especificidades do debate acerca da economia criativa no Brasil, e não para toma-lo de empréstimo para compreender o capitalismo cultural como um todo. Em outros termos, a FIRJAN é parte do objeto aqui delineado, é um agente interessado, como é o Ministério da Cultura e o SEBRAE. Importa a atuação desses agentes institucionais no interior de uma figuração mais ampla, que os envolve e, em grande medida, os determina. A discussão, o debate, os estudos e as políticas culturais inspiradas na economia criativa potencializam a expansão do capitalismo cultural brasileiro, a partir dos distintos usos e da legitimação que as relações entre cultura e mercado vem granjeando. O capitalismo cultural brasileiro não começou na década passada, ocorre

${ }^{6}$ Gerente responsável pelas indústrias criativas no âmbito do sistema FIRJAN cuja informação foi passada por meio de entrevista realizada na sede da instituição, no centro do Rio de Janeiro, em novembro de 2012. 


\section{A economia criativa no Brasil: o capitalismo cultural brasileiro contemporâneo.}

que, agora, grande parte dos códigos ético-estéticos dos principais grupos de poder (corporações, artistas, empresários, produtores culturais, gestores, etc.) estão sendo forjados a partir do cruzamento cotidiano entre mercado e cultura. Desse modo, a FIRJAN se locomove e se posiciona diante de uma figuração que a envolve, no interior da qual, como qualquer outra organização corporativa, ela busca compreender e atuar. Para tornar esse exercício mais fecundo, inserindo a própria FIRJAN no movimento, julgamos que o melhor guia e o mais seguro catalisador empírico é olhar para a viga mestra de sustentação da economia brasileira contemporânea: o consumo das famílias. A partir desse eixo talvez se constate que o conjunto de atividades, produtos, serviços e negócios que a esfera cultural aciona e galvaniza seja bem maior do que se imagina, inclusive a própria FIRJAN.

Em 2012 o PIB brasileiro cresceu 0,9\%. Embora considerado muito modesto, no terceiro trimestre daquele ano o Produto Interno Bruto alcançou um crescimento de 0,6 , em grande medida alavancado pelo crescimento ininterrupto do consumo das famílias. Estima-se, de acordo com dados do IBGE, que o consumo das famílias representou cerca de $60 \%$ do PIB brasileiro em 2012. Esse crescimento vem se mantendo desde o último trimestre de 2003, totalizando 35 trimestres de crescente alta. $\mathrm{O}$ consumo simbólico-cultural não tem passado incólume a esse crescimento, pelo contrário, parte do seu próprio crescimento tem dinamizando setores tradicionais e consolidados da economia brasileira, como o setor industrial, eixo de atuação da FIRJAN. O gasto total das famílias brasileiras com cultura representava, em 2002/2003, 3\% do orçamento familiar, em 2008/2009 esse mesmo gastou alcançou o percentual de 4,5\%. Como as demais modalidades de consumo, o consumo cultural se concentra nos estratos mais elevados da renda. Os que recebem mais de $\mathrm{R} \$ 1500$ respondem por cerca de $79 \%$ do consumo global. O crescimento de 1,5\% em seis anos (2003/2009) não representaria um aumento substancial se não tivesse sido acompanhado de um aumento geral nos níveis de renda, do aumento do poder de compra do salário mínimo e na expansão do assalariamento de um modo geral, fatores que, combinado a outros, alteraram o desenho da estratificação brasileira. De acordo com os dados da Fundação Getúlio Vargas (FGV), entre 2003 e 2009 cerca de 30 milhões de pessoas ascenderam à chamada classe $C$ (onde se inserem as famílias com renda entre $\mathrm{R} \$ 1610$ e $\mathrm{R} \$ 6.941$ ), a nova classe média, ou segunda classe média, ou mesmo, como sustenta Jessé Souza $^{7}$, a nova classe trabalhadora; no mesmo período, cerca de 7 milhões de brasileiros ascenderam aos estratos B (onde se inscrevem as famílias com renda de $R \$ 6.941$ a $R \$ 9050$ ) e A (famílias com rendimento acima de $R \$ 9050$ ). Durante o período analisado pela fundação, o maior crescimento proporcional foi entre os segmentos A e B, que, no intervalo estudado, cresceu cerca de 55\%, saltando de 13

\footnotetext{
${ }^{7}$ SOUZA, Jesse. Os batalhadores brasileiros: a nova classe média ou a nova classe trabalhadora? Belo Horizonte, Editora UFMG, 2010.
} 
Elder P. Maia Alves

Carlos Alexsandro de Carvalho Souza

milhões de pessoas, em 2003, para 20 milhões, em 2009. Segundo os cálculos da fundação, o Brasil tem hoje cerca de 73,3 milhões de pessoas nos estratos E (com renda abaixo de $R \$ 1008$ ) e $D$ (que possuem renda entre $R \$ 1008$ e $1610 R \$$ ), perfazendo um total de cerca de $40 \%$ da população brasileira; ao passo que o segmento C abriga aproximadamente de $50 \%$ da população nacional, ficando os Estratos A e B com 10\% do contingente populacional nacional.

O aumento de 1,5\% dos gastos com cultura pelas famílias brasileiras, entre 2003 e 2009, foi alavancado exatamente pelos segmentos A, B e C. Esse aumento significou uma alteração geral nos níveis da demanda e do funcionamento de diversos mercados culturais, implicando alterações na gestão; nas formas de captação de recursos; nas estratégias de financiamento; na criação de novos ambientes de negócios; no exercício da capacidade criativa direcionada para a produção de conteúdos e nos impactos políticos e governamentais da esfera cultural. De acordo com os dados da FIRJAN (o IBGE ainda está consolidando uma conta satélite unificada para a cultura), em 2011, as indústrias criativas responderam por R 110 bilhões do PIB brasileiro. Desse montante, aproximadamente 55\% (R\$ 57 bilhões - dados de 2009) derivaram do consumo das famílias. No computo geral do consumo, cerca de $75 \%$ é realizado no lar, ao passo que os outros $25 \%$ ocorrem fora do ambiente doméstico. É precisamente, aqui, que a atuação de entidades como FIRJAN (e diversas outras, como a FIESP8, a FECOMÉRCIO SP9 e o SEBRAE) se justifica e ganha inteligibilidade. A figura abaixo permite visualizar os labirintos de organização do mercado de bens e de serviços simbólico-culturais no Brasil.

\footnotetext{
${ }^{8}$ Federação das Indústrias do Estado de São Paulo.

${ }^{9}$ Federação do Comércio de Bens, Serviços e Turismo do Estado de São Paulo.
} 
A economia criativa no Brasil: o capitalismo cultural brasileiro contemporâneo.

Figura 2. Composição do mercado de bens simbólicos no Brasil
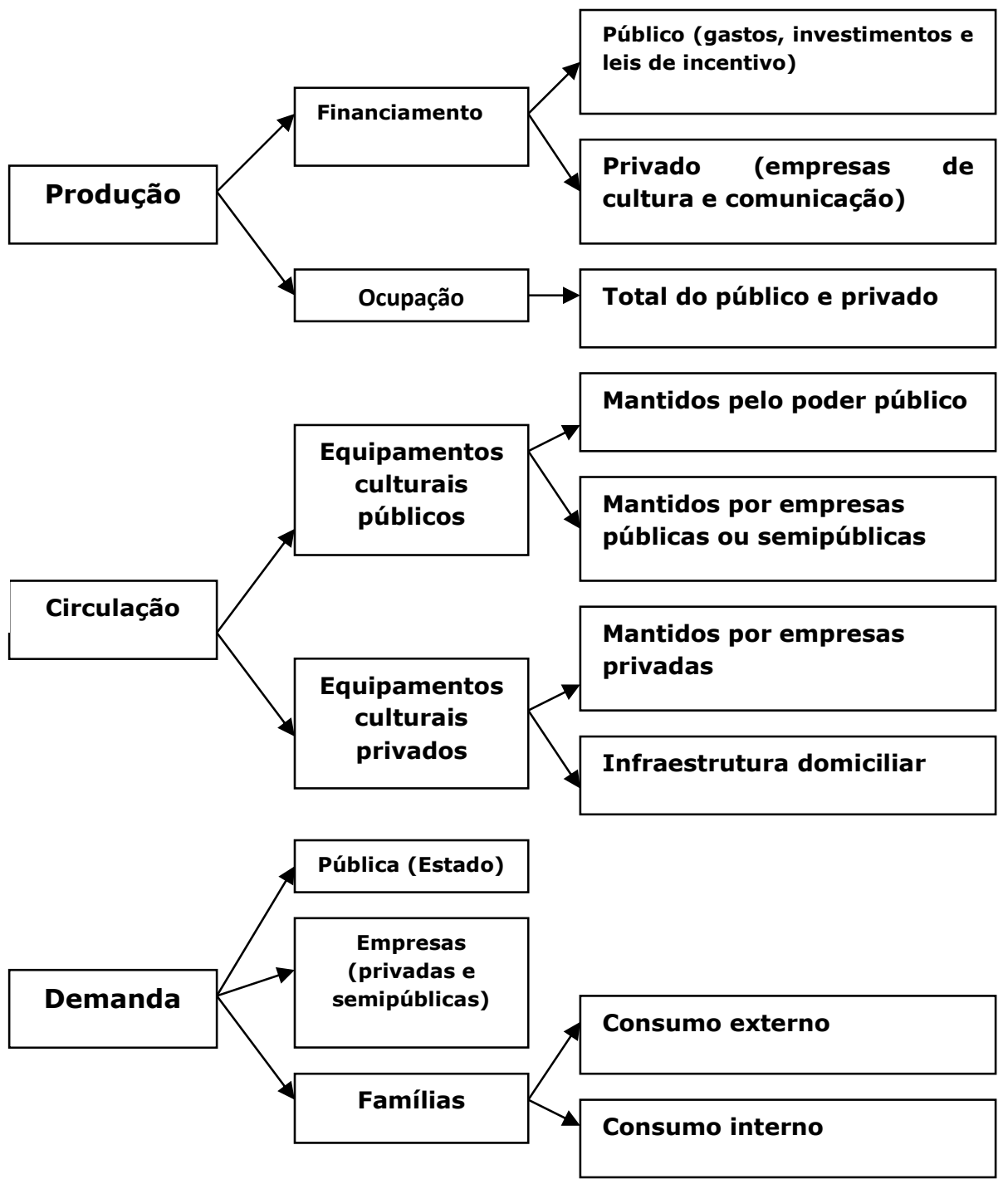

Fonte: Elaborado pelo autor.

Tendo no horizonte a figura 1, é possível mobilizar mais alguns dados para reforçar a hipótese mobilizada antes, qual seja: os principais agentes políticoculturais tradutores do tema da economia criativa no Brasil (MINC, FIRJAN e SEBRAE) se locomovem e se posicionam, de acordo com as suas missões institucionais, em meio a uma figuração mais ampla, a expansão e complexificação do capitalismo cultural brasileiro. Nesses termos, como já dito, o tema é caudatário dessa expansão e impacto e, ao mesmo tempo, cria novas dinâmicas econômicas, 
Elder P. Maia Alves

Carlos Alexsandro de Carvalho Souza

pois vem ganhando profusão e legitimação no ambiente empresarial-corporativo e governamental. De acordo com a Pesquisa de Orçamento Familiar (POF), 2009/2010, do IBGE, os maiores gastos das famílias brasileiras são com habitação $(35,9 \%)$, alimentação $(19,8 \%)$ e transporte $19,6 \%$. Cada um desses setores envolve e exige as atividades e os serviços criativos que compõem os núcleos criativos delimitados pela FIRJAN. Esses segmentos oferecem, ainda, possibilidades de análise a partir dos cruzamentos com outros setores e também por meio da abertura que estabelecem com as diversas dinâmicas criativas. Basta explorar, no entanto, um exemplo. Como aponta a POF, o maior gasto das famílias é com habitação, que revela o crescimento do mercado da construção civil nos últimos anos, catapultado pelo mesmo fenômeno de crescimento da renda e também pelas políticas de crédito para a aquisição da casa própria. Apenas de 2007 para 2008, verificou-se um crescimento de $80 \%$ no número total de imóveis vendidos e financiados. De acordo com o Banco Central, o numero de unidades habitacionais financiadas saltou de 300 mil, em 2003, para mais de 700 mil, em 2009. Segundo a mesma instituição, em 2000, o volume de crédito total disponível na economia brasileira representava $28,3 \%$ do PIB, em 2009 , era $45 \%$. Conforme o IBGE, em 2010, o setor da construção civil respondeu por 6,2\% do total do PIB nacional. Entre 2003 e 2012 o mercado de decoração de interiores cresceu 500\%. Em 2012, por exemplo, o setor de acabamento e decoração de interiores faturou $\mathrm{R} \$ 43$ bilhões. Ora, para a criação dos objetos, utensílios, quadros, peças, móveis, suportes, texturas, formas, materiais e demais artefatos que compõem os interiores domésticos são necessários empresas de design, decoração, arquitetura, artesanato, engenharia e movelaria, setores presentes no núcleo criativo do estudo-guia da FIRJAN. Dificilmente o modelo empírico da organização (e demais modelos, do IBGE, IPEA e universidades) contabiliza os impactos financeiros deste setor para as indústrias criativas, pois os limites são tênues e as interfaces muito complexas e difíceis de capturar. Por exemplo, todo o setor da construção civil está ligado à dupla dinâmica do consumo cultural dentro e fora do lar, pois, ao mesmo tempo em que reordena a malha urbana das cidades, especialmente no Rio de Janeiro (objeto de agudas transformações urbanas por ocasião dos grandes eventos de 2014 e 2016, Copa do Mundo de Futebol e Jogos Olímpicos, respectivamente), onde os investimentos tem se concentrado na edificação de equipamentos culturais (museus, centros de diversão, espaços culturais, cinemas, livrarias, etc.), também fornece incentivos para o consumo no lar, com novas e sofisticadas infraestruturas domésticas.

Tais infraestruturas são planejadas oara abrigar o uso das tecnologias digitais no lar, que compreende uma nova ecologia sócio-técnica: aparelhos digitais, interfaces e redes de integração de serviços de informação e entretenimento ( $\mathrm{TV}$, telefone, internet móvel, etc.). A aquisição, mediante financiamento e outras formas de compra, de equipamentos culturais domésticos 


\section{A economia criativa no Brasil: o capitalismo cultural brasileiro contemporâneo.}

(TV de plasma, LCD e LED, câmara digital, notebook, aparelho de MPT|IPOD, DVD Player, filmadora digital, entre outros) vem crescendo substancialmente no país. A venda de câmeras digitais, por exemplo, cresceu 17\% de 2010 para 2011. De acordo com levantamentos recentes, como o realizado pelo Instituto DATAFOLHA, 74\% da classe média intermediária no Brasil (segmento C) possui o aparelho de DVD player em casa, ao passo que $36 \%$ do mesmo segmento possui câmera digital. O que não foi mensurado ainda foram os impactos reais da Lei ${ }^{\circ}$ 12.485, Lei de Comunicação Audiovisual de Acesso Condicionado, de 12 de setembro de 2011, que, entre outras mudanças, traz, como princípios legais: a promoção da diversidade cultural e das fontes de informação, produção e programação; a promoção da língua portuguesa e da cultura brasileira; o estímulo à produção independente e regional e o estímulo ao desenvolvimento social e econômico do País. A lei tem vicejado discussões, seminários, audiências públicas e ações na justiça, mas, sobretudo, tem impactado na estrutura do mercado de TV por assinatura, pois, como estabelecem os princípios legais, exige 03h30min minutos de programação nacional por parte dos canais. Diante do fremente crescimento do mercado no Brasil, a partir de 2009, as produtoras audiovisuais estão sendo acossadas e chacoalhadas para produzirem tais conteúdos. Mirando as implicações práticas da lei, a RIO FILME (empresa de produção e distribuição da Prefeitura Municipal do Rio de Janeiro), anunciou, em março de 2013, a criação do Programa de Capacitação RIO FILME/SENAI RIO 2013. De acordo com essas instituições, o programa passou a oferecer, para o primeiro semestre de 2013, 14 cursos de formação na área do audiovisual (tratamento de imagem, roteirização, fotografia, técnico de desenho, operador de câmara etc.), distribuídos por 25 turmas, totalizando 550 vagas, das quais 5 turmas e 110 vagas serão destinadas aos moradores residentes em comunidades pacificadas, que foram dispensados do pagamento da taxa de inscrição (que varia de $R \$ 85$ a $R \$ 150$ ). Durante o lançamento do programa, o prefeito do Rio, Eduardo Paes, e o diretor presidente da RIO FILME, Sérgio Sá Laitão, além de destacarem a economia criativa como uma vocação central para a cidade, assinalaram o crescimento da demanda e dos investimentos em torno do audiovisual carioca, e a necessidade de formação de profissionais criativos para atender as demandas da Lei 12.485. Para tanto, a RIO FILME, anunciou, durante o Rio Content Market (maior evento de mercado e negócio de televisão da América Latina), em fevereiro de 2013, a criação de uma linha de financiamento exclusiva para a televisão fechada, com recursos de $R \$ 10$ milhões para 2013. No total, a empresa anunciou que investirá, em 2013, $R \$ 49,5$ milhões, destinados às seguintes áreas: desenvolvimento, distribuição e produção de longas; desenvolvimento e produção de conteúdo para TV; expansão do parque exibidor de cinema; e realização de eventos setoriais. Segundo essa mesma senda, a família Barreto (proprietária de uma das maiores produtoras de cinema do país e responsável por uma relevante linhagem de cineastas e produtores nacionais), 
Elder P. Maia Alves

Carlos Alexsandro de Carvalho Souza

anunciou a criação da LCTV, braço operacional criado para produzir filmes direcionados à TV por assinatura. Os representantes da família declararam ${ }^{10}$ que as criações para TV passarão a representar $40 \%$ dos negócios e das atividades da produtora, mesmo percentual do cinema, as demais atividades e projetos $(20 \%)$ serão destinadas aos filmes institucionais. De acordo com os dados apresentado no Rio Content Market, serão necessárias, no mínimo, 2000 mil horas de conteúdo nacional por ano para atender a exigência de cota estabelecida pela lei 12,485, o que produzirá um crescimento estratosférico de recursos financeiros no setor, saltando de $R \$ 74$ milhões, em 2011, para $R \$ 1,7$ bilhão, em 2016, engendrando, por conseguinte, cerca de $86 \mathrm{mil}^{11}$ postos de trabalhos no segmento audiovisual brasileiro.

Entre 2009 e 2010 o número de assinantes e usuários diretos do serviço da TV por assinatura cresceu 38\%, alcançando, no final de 2012, 16 milhões de assinantes. Calculando-se a média de habitantes por domicílio no Brasil (3,3 habitante por domicílio), o número de usuários do serviço sobe para 53,4 milhões de habitantes, ou aproximadamente $27 \%$ da população brasileira. O maior crescimento no número de assinantes tem-se registrado no Nordeste, $43,9 \%$ entre 2009 e 2011, no entanto, o Sudeste o Sul apresentam uma média de domicílios com o serviço cerca de nove vezes maior que o Nordeste. Dentro do crescimento verificado em 2011, o Piauí foi a unidade da federação com maior destaque, alcançando $81 \%$ de acrescimento em comparação com 2010, saindo do total de 26 , 614 lares com o serviço, em 2010, para 48.287 lares, em 2011 (ANATEL, 2011). As tecnologias mais utilizadas para a consecução dos serviços são o chamado meio físico confinado (utilização de cabos de fibra ótica); por meio radioelétrico de micro-ondas (chamado MMDS); por meio da faixa convencional de UHF (por meio de frequência especial para TV por assinatura) e, por fim, via satélite (chamado DTH). Esse último esteve em expansão em 2011, alcançando $54,8 \%$ da base total do serviço. A operadora NET/Embratel detém cerca de 50\% do número total de assinantes (8.494.999 milhões); e a SKY/Directv aproximadamente 32\% (5.038.863 milhões). De acordo com a ANCINE, com a aprovação da Lei 12.485, estima-se um aumento de $\mathrm{R} \$ 400$ milhões anuais no mercado do audiovisual brasileiro, incluídas as operações para televisão, cinema e plataformas digitais.

\footnotetext{
${ }^{10} \mathrm{http}: / /$ www.interjornal.com.br/noticia.kmf?canal=120\&cod=19768809

${ }^{11}$ http://www.culturaemercado.com.br/
} 


\section{A economia criativa no Brasil: o capitalismo cultural brasileiro contemporâneo.}

\section{Gráfico 2}

\section{Evolução do número de assinaturas}

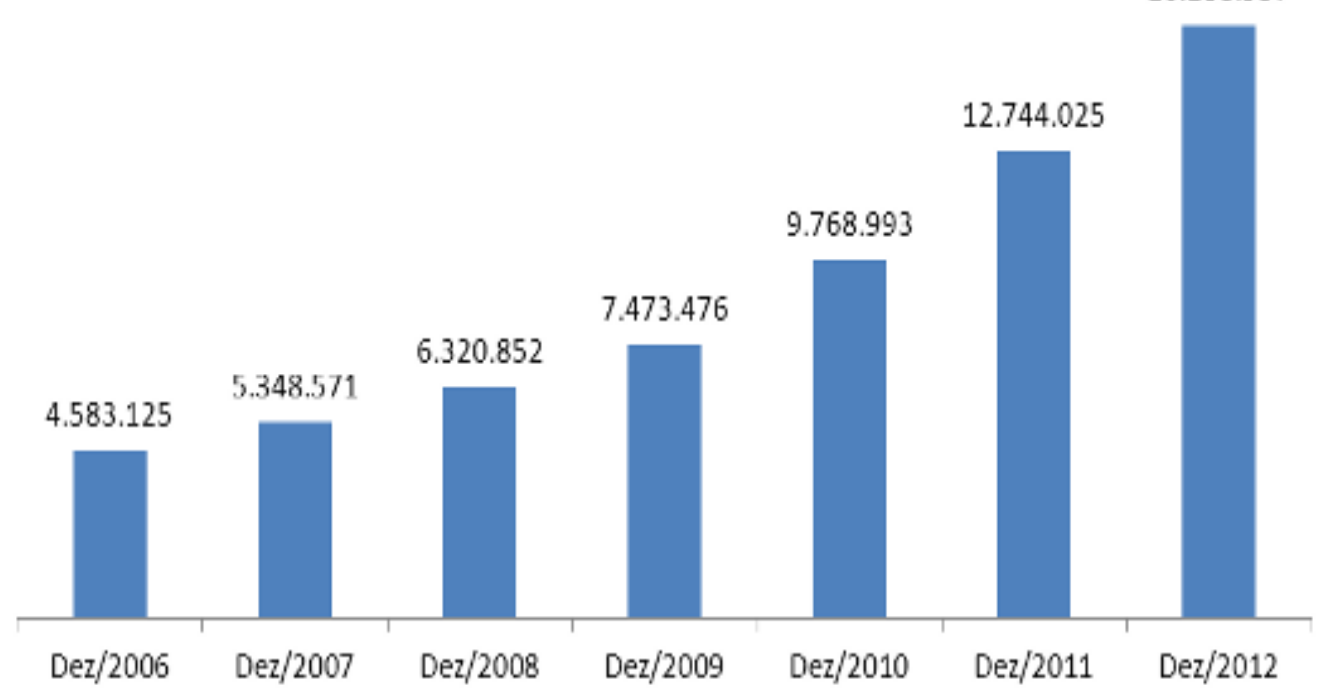

Fonte: ANATEL.

No decurso atual do processo de regulamentação e implementação da Lei 12.485 cabe a ANATEL ${ }^{12}$ estabelecer os procedimentos, prazos e critérios de definição e unificação das tecnologias, assim como as exigências para operar no setor. Por outro lado, fica sob a incumbência da ANCINE ${ }^{13}$ a tarefa de definir o que significa exatamente a classificação de "conteúdo brasileiro", empresa programadora, produtora e empacotadora brasileira, assim como a definição do que se julga como horário nobre. O objetivo maior, segundo a própria agência, é assegura o cumprimento da Emenda $n^{-0} 36$, de maio de 2002, assim como dispositivos posteriores que asseguram a inserção de conteúdos nacionais, a fim de promover a cultura nacional e regional, o estímulo a produção independente e a sua divulgação (ANCINE). Em nota esclarecedora sobre as instruções normativas que visam à regulamentação da lei, a agência assim se manifesta sobre a politica de cotas prevista na lei: "por fim, o Brasil ao assinar a Convenção Internacional sobre a Proteção e Promoção da Diversidade das Expressões Culturais (Decreto Legislativo n. 485, de 20/12/2006), obrigou-se a estabelecer uma política que preserve e fomente a diversidade cultural e regional. Portanto, a política de quotas estabelecida no projeto de lei aprovado não faz mais do que implementar esse

${ }^{12}$ Agência Nacional de Telecomunicações, ligada ao Ministério das Telecomunicações.

${ }^{13}$ Agência Nacional de Cinema, ligada ao Ministério da Cultura. 
Elder P. Maia Alves

Carlos Alexsandro de Carvalho Souza

objetivo constitucional do Estado brasileiro e o compromisso internacional assumido pelo Brasil ao aderir à Convenção da Diversidade Cultural". Esses princípios normativos, como veremos a seguir, constitui o cerne da estrutura dos códigos ético-estético de parte dos grupos de poder a frente das principais organizações governamentais de cultura no Brasil.

Diante do crescimento das demandas por conteúdos audiovisuais (o substancial aumento de salas de cinema e assinantes de TV paga atestam essa espiral de demanda), a ANCINE firmou contrato para que o BNDES seja o principal agente financeiro do Fundo Setorial do Audiovisual Brasileiro, dispositivo criado para planejar o desenvolvimento articulado da atividade audiovisual brasileira, que dispõe de uma linha exclusiva para conteúdos audiovisuais para a televisão. O acordo, firmado no fim de 2011, estabelece que serão repassados ao BNDES R\$ 2 bilhões até o final de 2015, para o desenvolvimento de um mercado de conteúdos para televisão, cinema e outras mídias (ANCINE). O Fundo Setorial do Audiovisual (FSA) foi lançado em 2008, desde então tem sido utilizado como potencial mecanismo de incentivo a produção audiovisual no Brasil e organização interna do setor, a partir de quatro linhas de ação (voltadas à produção, distribuição, comercialização de obras para cinema e televisão), totalizando um investimento global, desde 2008, de R $\$ 239$ milhões. De acordo com a ANCINE, FSA tem se destacado no o incremento da cooperação entre os diversos agentes econômicos, na ampliação e diversificação da infraestrutura de serviços e de salas de exibição, o fortalecimento da pesquisa e da inovação, o crescimento sustentado da participação de mercado do conteúdo nacional, e o desenvolvimento de novos meios de difusão da produção audiovisual brasileira." O BNDES foi escolhido pelo Comitê Gestor do FSA por sua vocação para o desenho de políticas de desenvolvimento, por sua expertise na administração de mecanismos financeiros e pelo fato de incluir, entre suas finalidades, o estímulo a agentes de desenvolvimento" (ANCINE, 2011).

Essas ações (o FSA e a Lei 12.485) concorrem para a consecução de um mercado inédito no Brasil: a integração horizontal e vertical do mercado audiovisual brasileiro, espraiado pelas salas de cinema, a televisão (sobretudo por assinatura) e diversos suportes digitais (principalmente aqueles com acesso a internet: computadores, celulares, tabletes, etc.). De acordo com a agência Com Sore, o consumo de vídeos online cresceu 18\% no Brasil, em 2012. O consumo cresceu mediante vídeos acessados em sítios ou por meio de aplicativos, presentes em sítios do Facebook, Yahoo e R7, bem como os canais que podem ser acessados dentro do ambiente do You Tube. Essa mudança está ocorrendo em razão das transformações dos códigos ético-estéticos, modelados, desde os anos 80, pelas aproximações entre arte, tecnologia e entretenimento, que tem transformado o fazer cinematográfico e televisivo, assim como os seus próprios ambientes empresarias de negócios. Para isso, os processos de transmidiação e convergência 


\section{A economia criativa no Brasil: o capitalismo cultural brasileiro contemporâneo.}

digital tem sido decisivos. Desde 2001 o publico total de cinema no Brasil (mesurado a partir da compra de ingressos para as salas) vem crescendo, mantendo-se acima dos 75 milhões de espectadores registrados em 2001; alcançando 117 milhões em 2004; oscilando negativamente entre 2005 e 2008, mantendo a média de 90 milhões; e, por fim, experimentando grande crescimento entre 2009 e 2011, quando alcançou 141,7 milhões, apresentando uma média de crescimento nesses três anos de $50 \%{ }^{14}$ em comparação aos quatro anos anteriores, 2005/2008. A renda global, por sua vez, vem apresentando um crescimento constante (com exceção do ano de 2005), totalizando um crescimento financeiro de 84\%, entre 2006 e 2011, obtendo a vultosa soma de R\$ 1.417 (um bilhão e quatrocentos e dezessete milhões de reais). Até 2009 o preço médio dos ingressos acompanhou o aumento da inflação, apresentando uma média de aumento de cerca de 5,4\%, entre 2004 e 2009. Em 2010 e 2011, todavia, os ingressos subiram acima da inflação, apresentando uma taxa média de 7,8\%. Esse fator não reduziu, no entanto, o crescimento de publico e de renda desses dois últimos anos. Entre 2002 e 2011 a dinâmica de espectadores dos filmes nacionais, não obstante, oscilou bem mais. Saltando de 7,8 milhões, em 2002, para 17,8 milhões, em 2011; alcançando o pico em dois anos: 2003 (22 milhões) e 2010 (25,6 milhões). Em 2011 o público de filmes nacionais foi de 17,8 milhões (12,6\% do público total).

Os espectadores dos filmes não nacionais (sobremaneira os norteamericanos), por sua vez, apresentaram um significativo crescimento nos dois últimos anos. Cada vez mais os grandes estúdios de Hollywood têm realizado filmes nos chamados países em desenvolvimento (notadamente aqueles que compõem os BRICS: Brasil, Rússia, Índia, China e África do Sul) e recrutado atores, diretores e equipes nesses países. Por exemplo, entre 2011 e 2012, três grandes produções foram filmadas no Brasil: Velozes e Furiosos 5 - Operação Rio; Os mercenários e a primeira parte de A Saga Crepúsculo - Amanhecer, que, no Brasil, amealhou a terceira bilheteria internacional, com US\$ 32 milhões. De acordo com Frédéric Martel, cerca de $60 \%$ do faturamento total dos estúdios de Hollywood são obtidos fora dos Estados Unidos, até os anos 90 era exatamente o inverso. Essas e outras mudanças alteraram a gestão e todo o sistema de produção norteamericano, que já vinha se dando desde os anos 60. Os grandes estúdios, cada vez mais, delegam para uma miríade de produtoras "independentes" o processo criativo (escolha de roteiros, locações, contratação de elencos, filmagens etc.), ficando o grande estúdio (Disney, Warner, Columbia, tec.) com a incumbência de captar os recursos necessários, controla-los e liberá-los (semelhante ao um banco: bancos do audiovisual norte-americano) e, por fim, realizar toda a campanha publicitária de distribuição do filme, chancelada pela marca secular de um grande estúdio. A maior penetração do cinema norte-americano não significa,

${ }^{14}$ Filme B (http://www.filmeb.com.br/portal/html/graficosetabelas.php). 
necessariamente, um recuo da cinematografia de países como a Índia, a Rússia, o Brasil e a redução, resignada, dos mercados dos filmes nacionais. Representa, antes, uma luta encarniçada por espaço estético e comercial, que mobiliza diversos interesses corporativos, empresariais e culturais em todo o mundo. $\mathrm{O}$ crescimento da indústria cinematográfica indiana (a chamada Bollywood) e a Lei brasileira n¹2.485 (lei da TV por assinatura) são exemplos incontestes a esse respeito. Os seis maiores mercados de Hollywood fora dos EUA são: China (US\$ 2,7 bilhões, entre 2011 e 2012); Japão (US\$ 2,4 bilhões); Grã-Bretanha (US\$ 1,7 bilhão); França (US\$ 1,7 bilhão); Índia (US\$ 1,4 bilhão) e Alemanha (US\$ 1,3 bilhão). O Brasil é o $10^{0}$ mercado, com US\$ 800 milhões.

A regularidade quanto ao aumento de público e, sobretudo, quanto à elevação da renda, tem dinamizado todo o negócio do audiovisual, especialmente no que toca a exibição. Eis aqui mais uma relação direta da indústria da construção civil com os negócios culturais, interface esta que atraí entidades com a FIRJAN. A espiral de crescimento do consumo das famílias tem produzido uma demanda por centros de compras e entretenimento, como os shoppings centers. Em 2006 eram 351 shoppings no país, em 2012 já eram 457, um aumento de 30\% em 7 anos. A esmagadora maioria das salas de cinema, hoje, se concentra nos shoppings, cujo total de salas passou de 1315, em 2006, para 2.502, em 2010, crescimento de mais de $90 \%$ em apenas 5 anos. Com efeito, muitos grupos de exibição, como o Grupo Severiano Ribeiro (proprietário da Rede Kinoplex) tem buscado expandir o numero de salas, notadamente nas médias cidades brasileiras. De acordo com o Jornal $O$ Valor Econômico, no início de 2013, o grupo contratou o banco de investimentos JP Morgan para captar recursos junto a sócios minoritários, capazes de, em parte, financiar o plano de expansão do grupo. A rede Kinoplex pretende construir mais 81 salas entre 2013 e 2015; hoje, no total, são 220, a maioria concentrada nas grandes cidades. Entre 2010 e 2012 o faturamento da empresa cresceu 35\%; saindo de $R$ \$ 200 milhões, em 2010, para $R$ \$ 270, em 2012. As perspectivas de demanda são muito animadoras, ressalta o presidente do grupo, Luiz Severiano Ribeiro Neto, uma vez que o Brasil é um país que apresenta uma das menores densidades de salas de cinema do mundo (a relação do número de salas com o total da população). O México, por exemplo, com uma população bem menor do que a brasileira (110 milhões de habitantes) possui o dobro de salas do Brasil, cerca de 5000 mil salas. O presidente do grupo ressalta ainda que parte do plano de expansão tem se valido de empréstimos disponibilizados pelo BNDES, através da linha de crédito Cinema Perto de Você, destinada à concessão de créditos para a construção de salas nas cidades com poucos cinemas e/ou nos bairros que não dispõem desse equipamento, com juros entre 0 e $4 \%{ }^{15}$.

\footnotetext{
${ }^{15}$ Jornal O valor: http://www.valor.com.br/
} 


\section{A economia criativa no Brasil: o capitalismo cultural brasileiro contemporâneo.}

Também no shopping centers se localizam a absoluta maioria das grandes livrarias brasileiras. Desde 2009 tem se verificado o aumento das livrarias que faturam entre $R \$ 7$ e $R \$ 10$ milhões por ano, saltando de apenas 3, naquele ano, para 17, em 2012. No final de 2011 o BNDES anunciou a liberação de um financiamento de $\mathrm{R} \$ 31,7$ milhões para a Livraria Cultura. De acordo com o banco, os recursos liberados destinaram-se a modernização dos equipamentos e instalações das livrarias já existentes e para a construção de novas lojas, em cidades como o Rio de Janeiro, Manaus, Recife, Curitiba, Campinas, São Paulo, Fortaleza e Porto Alegre. O modelo operacional das novas livrarias segue o já consagrado megastore, que, além da venda de livros, disponibiliza CDs, DVDs, auditórios para lançamentos e palestras, cafés, teatros e espaços lúdicos para crianças. Embora cresça a venda de dispositivos e aplicativos para a leiteira digital (notadamente os tablets e o kindle), a venda de unidades físicas ainda se destaca no mercado do livro. De acordo com os dados da Associação Internacional dos Editores (IPA), divulgados no final de 2012, o Brasil é o $9^{\circ}$ mercado editorial do mundo, comum faturamento, em 2012, de $R \$ 6$,2 bilhões e 469,5 milhões exemplares vendidos. Já o faturamento das companhias editoriais brasileiras alcançou, em 2011, o faturamento de $R \$ 4,8$ bilhões. Conforme a Câmara Brasileira do Livro, em 2011, o custo médio do livro foi reduzido em $6,1 \%$; no total as vendas aumentaram $7,2 \% \mathrm{e}$ as receita 7,4\%, descontada a inflação. Em 2011, verificou-se uma alta do maior comprador editorial (sobretudo de livros), o governo, que aumentou suas compras em $13,7 \%$; o governo corresponde a $39,5 \%$ das compras do mercado; já o consumo das famílias aumentou, em 2011, 3,34\%. Esse panorama aguça o interesse de editoras internacionais, a compra de $45 \%$ da editora Companhia das Letras, em 2012, expressa bem as estratégias e a magnitude dos negócios editorias no Brasil. 


\section{Gráfico 3.}

\section{MERCADO EDITORIAL}

Faturamento com vendas ao consumidor, em R \$ bilhões

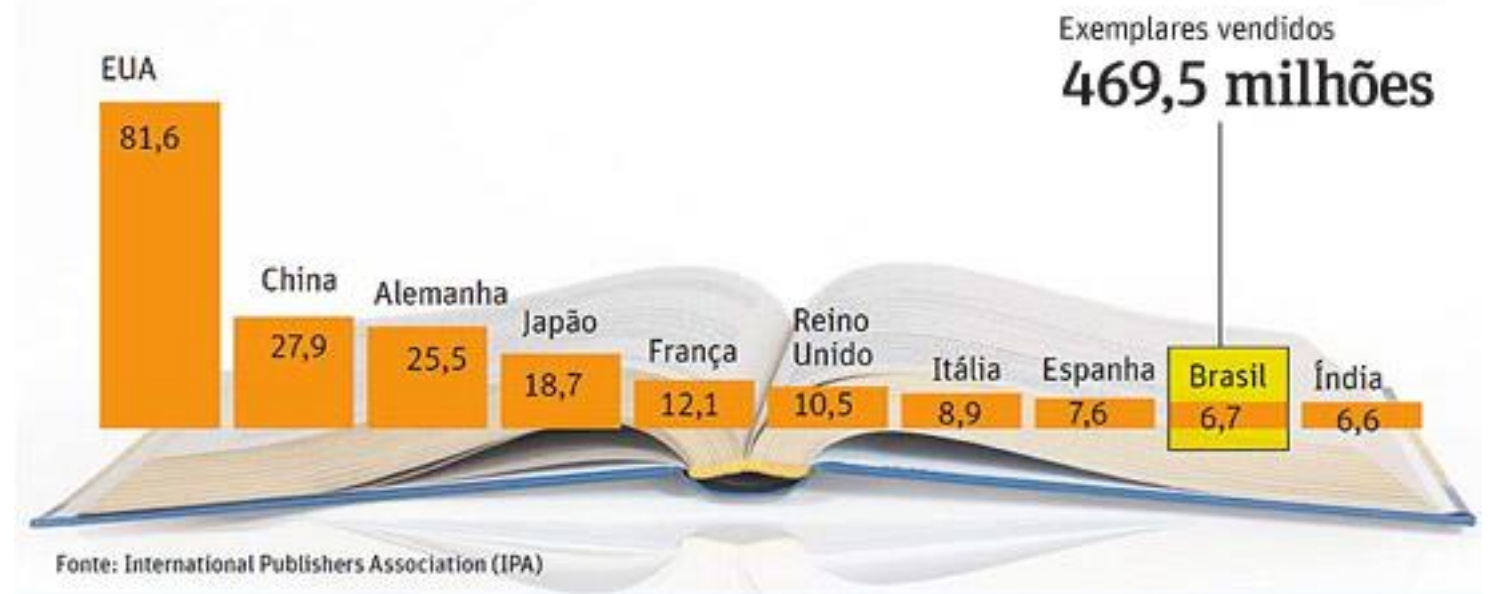

Fonte: Jornal Folha de São Paulo.

O exemplo inicial que acionou o fio da meada desse infinito novelo foi mobilizado para iluminar as relações entre os gastos das famílias com habitação e os mercados de cultura. Nessa senda, outro exemplo revela outra série de gastos, que são realizados a partir do uso do cartão de crédito. Segundo informações de empresas de consultoria especializadas ${ }^{16}$, o número de cartões de crédito no Brasil cresceu, entre 2006 e o primeiro trimestre de 2011, aproximadamente 100\%; saltando de pouco mais de 80 milhões de unidades, em 2006, para quase 160 milhões de unidades no primeiro trimestre de 2011. Diferente dos gastos com habitação, que não são realizados mediante o cartão de crédito, uma série de gastos que, devido a sua fluidez e multisetorialidade, não são computados como gastos culturais podem ser dissecados por meio dos usos dos cartões.

${ }^{16}$ Abecs e CVA Solutions 


\section{A economia criativa no Brasil: o capitalismo cultural brasileiro contemporâneo.}

Gráfico 4. Expansão no número de cartões de crédito no Brasil (em milhões de unidades).

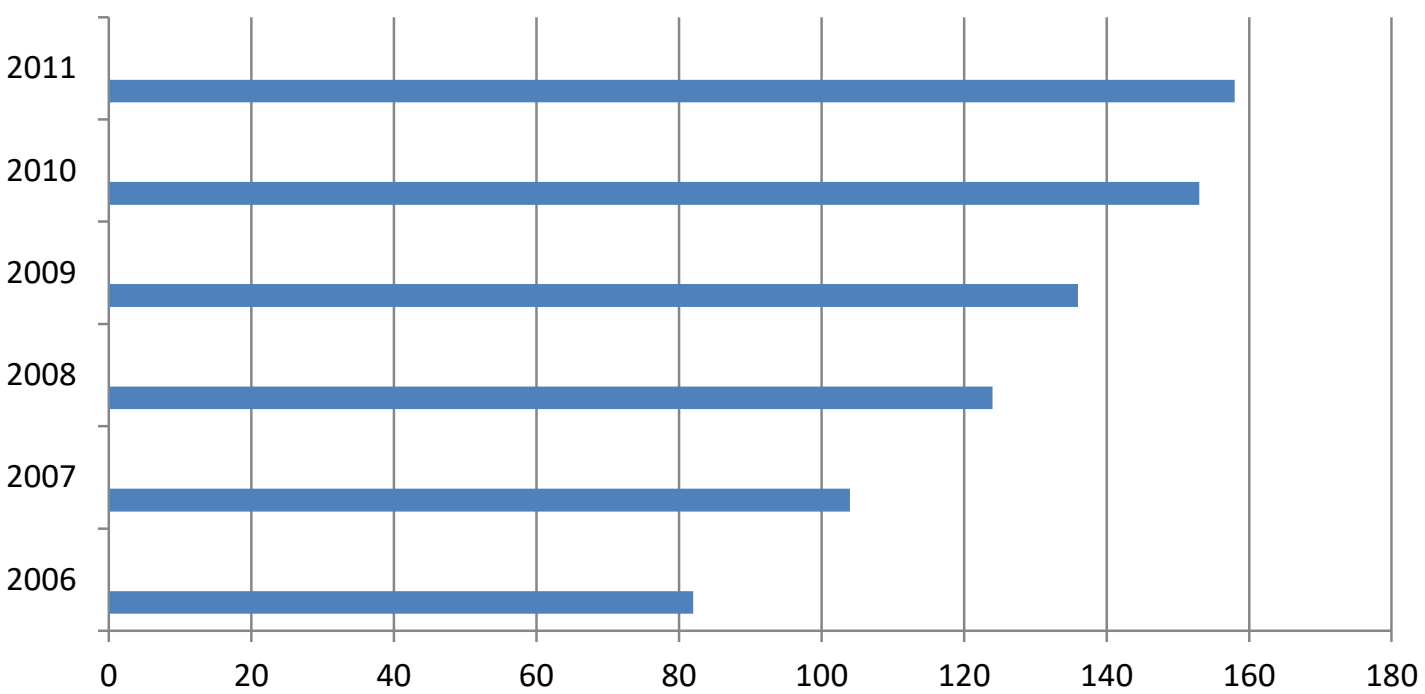

Fonte: Abecs e CVA Solutions (Apud Revista Exame, edição 995).

Além de expressar que a estrutura do gasto cotidiano das famílias tem no cartão de crédito seu principal instrumento de autofinanciamento, o gráfico 2 evidencia também as reais possibilidades de endividamento. De acordo com a mesma fonte do gráfico 2, durante o primeiro trimestre de 2011, os cartões de créditos no Brasil foram mais utilizados nas redes varejistas ( $29 \%$ do total), que inclui a compra de produtos perecíveis, eletrodomésticos e eletroeletrônicos, aparecendo logo em seguida (com 17\% do total) turismo e entretenimento, equivalendo-se (também com $17 \%$ do total) com restaurante, em seguida ( $11 \%$ do total) aparece o uso dos cartões no comércio automotivo, ficando o restante $(26 \%)$ com outros segmentos menos expressivos. Como no exemplo dos gastos com habitação, transporte e alimentação, os gastos com restaurantes, redes de varejo e comércio automotor exigem a atuação de segmentos e núcleos criativos (termos da FIRJAN). Por exemplo, os circuitos especializados do turismo e da gastronomia nos grandes centros urbanos (restaurantes), a compra de aparelhos digitais para o lar (redes de varejo) e comércio automotor (editoras especializadas, design de automóvel, pesquisa e desenvolvimento, publicidade na TV e internet), mas fiquemos apenas com o segmento turismo e entretenimento. 
Elder P. Maia Alves

Carlos Alexsandro de Carvalho Souza

\section{Gráfico 5 .Uso do cartão de crédito por segmento econômico durante o primeiro trimestre de 2011. \\ $1^{\circ} 29 \% ; 2^{\circ} 17 \% ; 3^{\circ} 17 \%$ e $4^{\circ} 11 \%$.}

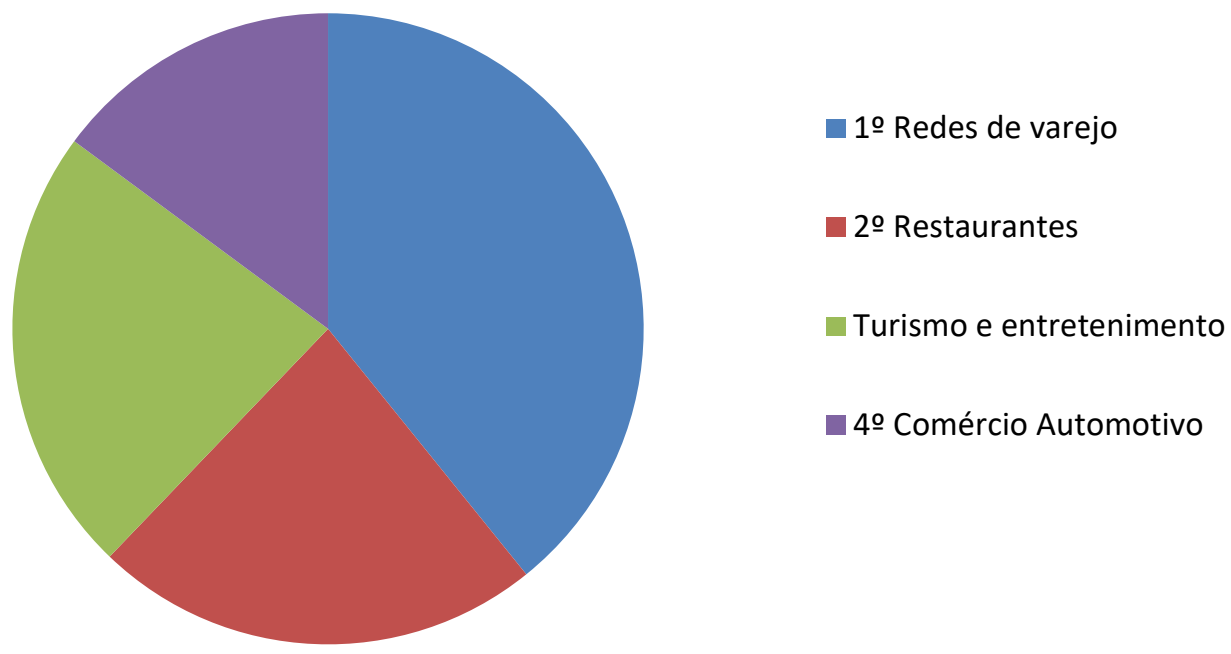

Fontes: Abecs e CVA Solutions (Apud Revista Exame, edição 995).

O entretenimento e o turismo encerram e potencializam uma miríade de atividades artístico-culturais. Todas, no entanto, têm em comum a feitura e o consumo fora do lar, o que, necessariamente, mobiliza uma rede de serviços, como alimentação, transporte e hospedagem, mesmo quando os frequentadores são do próprio perímetro urbano ou da mesma cidade. Os vetores que mais encabeçam os gastos nesse segmento ( $17 \%$ do total de gastos das famílias com o cartão de crédito em 2011) são os shows, a visitação aos equipamentos culturais públicos ou privados (cinemas, espaços culturais, balneários litorâneos, etc.) e o circuito ampliado das festas populares, como o carnaval e os festejos juninos. Repoisa aqui toda a discussão e ações, levada a cabo, por exemplo, pela FECOMÉRCIO de São Paulo, em torno das cidades criativas, territórios e polos criativos. O Conselho de Criatividade e Inovação da FECOMÉRCIO SP lançou, em março de 2012, o índice de criatividade das cidades. Tal indicador, cuja operacionalidade funciona em torno do índice de criatividade das cidades, está dividido em três variáveis: 1) classes criativas (número de empregados dos setores criativos; número de empregados total; proporção entre emprego criativo e emprego total por município); 2) condições econômicas (PIB per capta; porcentagem do PIB de serviços; empresas por habitantes e renda por habitante) e 3) condições sociais 


\section{A economia criativa no Brasil: o capitalismo cultural brasileiro contemporâneo.}

(porcentagem de pessoas com plano de saúde, Estado; porcentagem de emprego por habitante; vida perdida por violência; posse de microcomputador e saneamento básico). Levando-se em consideração essas variáveis e as somas gerais cruzadas da pontuação obtida por cada uma das 26 capitais brasileiras (mais Brasília) e os 26 estados da federação (mais o Distrito Federal), São Paulo é a cidade mais criativa, seguida por Porto Alegre e Belo Horizonte (o Rio de Janeiro aparece na $6^{0}$ colocação) ao passo que o Distrito Federal é a unidade federativa mais criativa, seguido pelos Estados do Rio de Janeiro e São Paulo.

Do mesmo modo que a FIRJAN, a FECOMÉRCIO busca se posicionar e se assenhorear do tema da economia criativa com vistas a criar modelos e ambientes específicos de negócios. Para tanto, lança mão de recursos técnicos, conceituais e políticos que, junto com uma série de outros agentes, concorrem para engendrar uma imagem institucional da cidade de São Paulo. Essa imagem passa, necessariamente, pela criação de atividades artístico-culturais que dinamizam o fluxo de consumidores, bens, serviços, impostos e receitas. De acordo com um questionário aplicado pela Revista Outlook, Anuário São Paulo, 2012, 70\% dos empresários e executivos entrevistados disseram que a economia criativa será muito relevante para os seus negócios nos próximos dez anos. São Paulo tem se tornado um polo de experimentação de modelos institucionais de eventos, como a Virada Cultural, o São Paulo Fashion Week e o Festival de Rock Lollapalooza. Diversas outras cidades têm ido na mesma direção, criando evento de arte e entretenimento que disseminem e projetem a cidade, explorando trações específicos da sua imagem ou adicionando outros. Por exemplo, segundo a Secretaria de Turismo do Rio de Janeiro, o Rock in Rio 2011 (evento que, nos últimos anos, converteu-se numa franquia, sendo realizada, de maneira inteiramente desterritorializada, em outras cidades, como Lisboa), por exemplo, movimentou, na edição 2011, aproximadamente US\$ 419 milhões, cerca de R $\$ 653$ milhões, com uma frequência de 700 mil espectadores, sendo que desses 315 milhões foram turistas estrangeiros, ocupando cerca de $98 \%$ da rede hoteleira da cidade durante o período de realização do evento. Os gastos dos turistas foram estimados em US\$ 233 milhões. Os 80 mil ingressos da venda antecipada do Rock In Rio 2013 foram vendidos em 52 minutos, um recorde absoluto. Outro evento menos robusto, mas não menos importante, decisivo para a formação dos nacos de prestígio envolvendo a cidade, o estado, as marcas corporativas (como, por exemplo, o Banco Itaú, o Banco do Brasil e o BNDES), os artistas e intelectuais locais e nacionais, diz respeito à Festa Literária Internacional de Paraty (FLYP), pequena cidade do Oeste do Estado do Rio de Janeiro, com cerca de 35 mil habitantes. De acordo com a organização do evento $^{17}$, durante a feira de 2011, que se realizou entre os dias 06 e 10 de julho, a cidade movimentou cerca de $\mathrm{R} \$ 6$ milhões, dinamizando a economia local através

${ }^{17}$ Matéria publicada no Jornal O globo do dia 11 de julho de 2011. 
Elder P. Maia Alves

Carlos Alexsandro de Carvalho Souza

da criação de 400 empregos temporários e a presença de 20 mil turistas exclusivamente para a festa.

Do mesmo modo que as marcas corporativas, as cidades estão se esmerando para construir as suas marcas urbano-institucionais. Mais uma vez, o exemplo do Município de São Paulo é emblemático a esse respeito. A partir de diferentes gestões e balanças de poder (ELIAS, 2000) que envolveram agentes variados (empresas de saneamento e arquitetura, artistas, políticos, intelectuais, órgãos de gestão urbana e organizações de moradores), a prefeitura de São Paulo, desde os anos oitenta do século passado, tem implementado ações com vistas a requalificações de antigos prédios, edifícios e instalações, buscando requalificar esses espaços como lugares de visitação e fruição artístico-cultural. Nos anos noventa, a partir de projetos do governo federal, como o Monumenta, por exemplo, a prefeitura promoveu uma série de intervenções urbanas, dotando antigos prédios e palácios das instalações adequadas para a fruição arquitetônica, criando rotas e destinos culturais em bairros específicos da cidade, como República, Luz e bom Retiro. O objetivo primeiro, diante da consolidação de outras modalidades de turismo, como o turismo de negócios, o turismo gastronômico, foi engendrar na cidade uma vocação para o chamado turismo cultural, concentrado no chamado arqueturismo - modalidade de turismo destinada à fruição de edificações e espaços arquitetônicos, como igrejas, palácios, museus, teatros, entre outros. Em 2012 o local mais visitado na cidade foi MASP; 14\% dos turistas estrangeiros e $26 \%$ dos turistas nacionais visitaram aquele equipamento cultural. De acordo com a Organização Mundial do Turismo (OMT), o turismo cultural corresponde a 10\% de toda a economia do turismo mundial, que, em 2010, alcançou a cifra total de \$ 6 trilhões. A julgar pelos recursos anunciados para o programa de incentivo e qualificação dos equipamentos arquitetônicos das cidades históricas (PAC das Cidades Históricas) que, entre 2013 e 2015, destinará R\$ 1 bilhão para 44 cidades brasileiras, essa modalidade de consumo turístico ganhará vigor nos próximos anos. Esses arranjos concorrem para criar as condições políticas, estéticas e institucionais para o aumento do turismo cultural, que passa a figurar nas estratégias de construção dos destinos, tanto por parte dos governos, das empresas públicas e, sobretudo, pelas grandes agências de viagens, como a CVC. Apenas em 2010 essa agência brasileira transportou cerca de 2,5 milhões de turistas, contando com mais de cem destinos e setenta roteiros, entre eles o interior do Nordeste e as cidades europeias, como Paris.

A região do centro de São Paulo foi aquela que experimentou com maior contundência as intervenções que pretendiam requalificar antigas áreas degradadas e abandonadas, algumas delas ocupadas (como palácios e casarões do século XIX) por moradores de rua e por integrantes do movimento sem teto. No decurso da última década do século $X X$, nada menos que onze intervenções foram realizadas sob a égide desse objetivo, que mobilizou diferentes interesses 


\section{A economia criativa no Brasil: o capitalismo cultural brasileiro contemporâneo.}

econômicos e mobiliários: novo Vale do Anhangabaú (1991), Bolevard São João (1991), Projeto Sé-Arouche (1992), Centro Cultural dos Correios (1997), Praça Ramos de Azevedo (1999), Shopping Light (1999), Centro Cultural Banco do Brasil (2000), Restauração do Museu de Arte Sacra (1999), Complexo Cultural Estação Júlio Prestes (1999), Pinacoteca do Estado (1999), Jardim da Luz (1999), Theatro São Pedro (1997). No decurso da década passada novas intervenções foram realizadas (Estação da Luz - 2004, Igreja de São Cristóvão - 2001, Hotel Flórida I Universidade Livre de Música - 2002, Casarão Santos Dummond।Museu da Energia - 2005, Museu do Imaginário do Povo Brasileiro, antigo Dops - 2002).

Como salienta Kara José (2007), por meio de uma pesquisa minuciosa, boa parte dessas intervenções foram realizadas na região da Luz (onde se concentram cerca de quinze equipamentos culturais públicos), cuja gênese remonta aos anos oitenta, com o Projeto Luz Cultural, e que alcança o pináculo com as reformas e restauração da Sala São Paulo, da Estação Júlio Prestes e da própria Estação da Luz, concluídas no início da década passada. Desde meados dos anos noventa do século passado a região já desponta como o principal polo cultural da cidade, concentrando, em decorrência do numero de visitantes, uma variedade de serviços urbanos, alimentação, transporte e bares. Para esses equipamentos culturais, após as inaugurações, destinaram-se companhias de música, exposições, espetáculos e apresentações em geral, forjando a ideia de âncora cultural, a parir da qual outros polos culturais surgiriam e um sem número de atividades seria sustentadas e viabilizadas mediante a dinamização de determinadas âncoras culturais, que não podem prescindir da atuação das marcas corporativas, como as indústrias de alimentos, de material esportivo, agencias publicitárias, entre outras. Assim como São Paulo, outras cidades brasileiras (não sem tensão, lutas e toda sorte de exclusão) tem buscado construir as suas marcas institucionais urbanas. Os cinco principais centros culturais e museais da cidade de São (Centro Cultural Banco do Brasil - CCBB; o Museu de Arte de São Paulo - MASP; a Pinacoteca do Estado; o Itaú Cultural e o Museu da Imagem e do Som - MIS) receberam juntos, em 2012, cerca de 2,7 milhões de visitantes (fonte).

Mesmo os museus, esses lugares de destaque da cultura, caíram no regime do hiper, com orçamentos colossais, suas estruturas futuristas cada vez mais tecnológicas, cada vez mais monumentais e espetaculares. O momento é da arquitetura emocional, mais à espreita de experiências imediatas que de iniciação e elevação espirituais. Depois do Beaubourg, o universo do museu é cada vez mais estruturado pelas lógicas do espetáculo, do novo, da sedução, que são as mesmas da moda...O museu era lugar de recolhimento, e ei-lo agora um espaço de recreação destinado ao consumo visual e hedonista do grande público.....Ao mesmo tempo, o museu afirma-se cada vez mais como um elemento do desenvolvimento urbano, o exemplo por excelência é o de Bilbao, que apelou para Frank Gehry, um arquiteto de renome, a fim de que construísse um extraordinário museu-escultura, 
Elder P. Maia Alves

Carlos Alexsandro de Carvalho Souza

o Guggenheim, que não dispõe de obras própria. O resultado é que, em dez anos (o museu abriu em 1997) a cidade ganhou notoriedade internacional que vários séculos de história não haviam lhe trazido. (LIPOVETSKY E SERROY, 2011).

O processo descrito por Lipovetsky, Serroy, José e outros autores tem passado, necessariamente, por políticas de incentivo às atividades e serviços criativos. Entre São Paulo e Rio, por exemplo, há uma luta silenciosa, que consiste em conquistar e afirmar a marca da cidade criativa brasileira. Ambas buscam reunir subsídios (investimentos, estudos, indicadores, congressos, políticas, planejamento, ações e apoio) que lhes permitam não só atrair investimentos por conta as suas atividades criativas (carnaval, música e cinema, no Rio; publicidade, gastronomia e moda, em São Paulo) como também, mediante essas mesmas atividades criativas, difundir a ideia-valor de centro criativo nacional. Em novembro de 2012, por exemplo, foi realizado na cidade do Rio o $1^{\mathrm{o}}$ Festival Internacional de Criatividade (CRIO), no âmbito do Fórum e Bienal Mundial da Criatividade. O evento foi realizado no Píer Mauá, região da zona portuária da cidade, onde está se operando as maiores transformações urbano-culturais da cidade, com a construção de museus, galerias, centros comerciais, corporativos e residenciais. Durante o evento, que contou com o apoio de entidades como o SEBRAE RJ, a FIRJAN, empresas de design, moda e publicidade, além da Prefeitura do Rio de Janeiro, ocorreram palestras, exposições de arte, seminários e a apresentação, em stands, das ações institucionais realizadas pelos organizadores do evento. O tema do evento foi "Redesign e transformação urbana", escolhido pela prefeitura municipal da cidade e a principal empresa organizadora do evento, a Luminosidade (a mesma responsável pelos dois maiores eventos de moda do Brasil: São Paulo Fashion Week e Fashion Rio) como norte de direcionamento para produção de valor envolvendo os espaços urbanos da cidade e as criações do design. O evento teve como sede a cidade do Rio porque, em 2010, a rede de agentes que dá vida ao Fórum Mundial da Criatividade, concedeu ao Rio o título de Distrito criativo, ingressando, assim, no seleto grupo de 14 regiões mundiais que compõem a DC Network - Districts of Creativity. Não por acaso, o evento foi realizado no Píer Mauá, o espeço pretende se transformar na principal âncora urbano-cultural da cidade. Ademais, transformar antigas regiões portuárias e industriais abandonadas em espaços de empreendedorismo criativo vem se tornando uma regularidade em todo o mundo, a exemplo das cidades de Lisboa, Londres e Buenos Aires. 


\section{A economia criativa no Brasil: o capitalismo cultural brasileiro contemporâneo.}

Figura 3. Cartaz do $1^{0}$ Festival Internacional de Criatividade (CRIO)

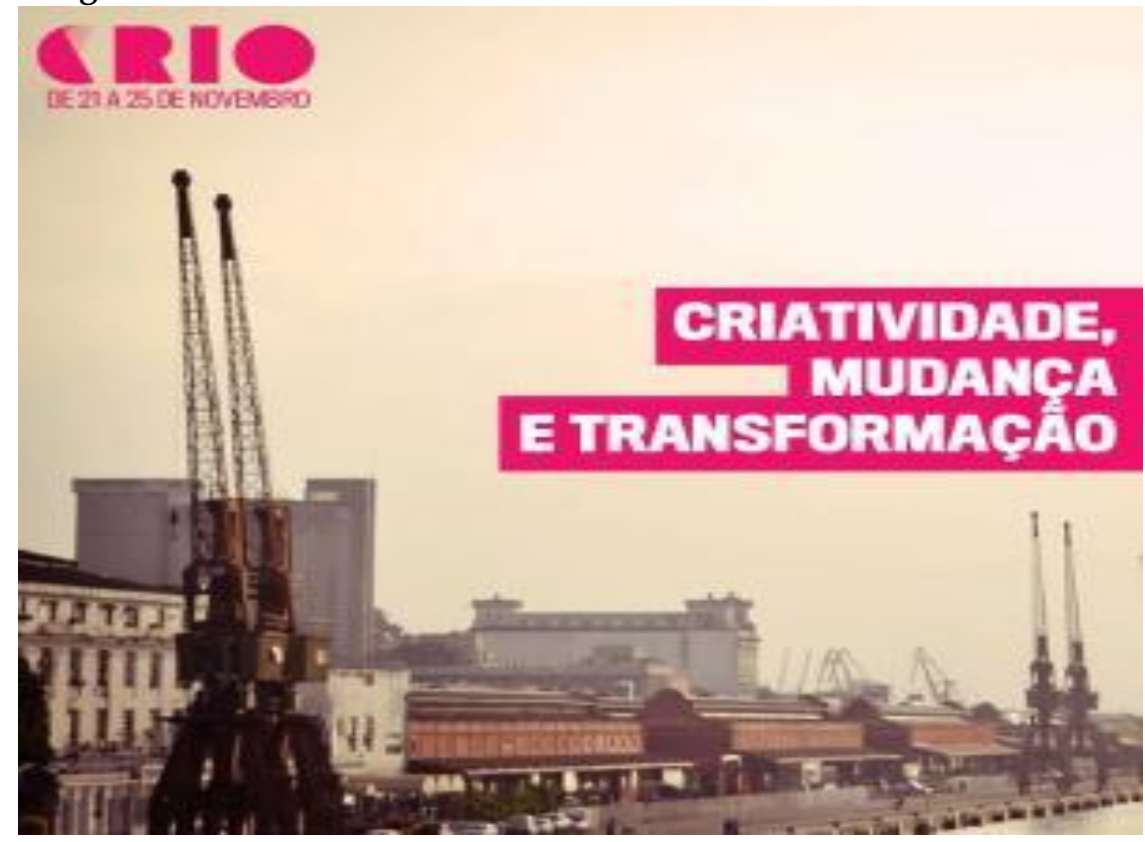

Fonte: http://www.ebc.com.br

Criar as condições para o consumo do entretenimento-turismo tem sido o norte principal de muitas das esferas da administração pública. Um das principais implicações é o aumento substancial na arrecadação de impostos. Durante os festejos juninos de 2011 na Bahia cerca de 300 mil pessoas passaram pela rodoviária da cidade de Salvador, segundo a Agência de Regulação de Serviços Públicos e Energia do Estado da Bahia (AGERBA), cerca de 200 mil pessoas utilizaram o sistema de navegação Ferry Boat, que dá acesso aos municípios da Ilha de Itaparica e a região do Recôncavo. Segundo a Polícia Rodoviária Federal (PRF), do dia 22 ao dia 25 de junho deste ano, o aumento do fluxo de carros na BR 324 foi de $150 \%$ em comparação a um fim de semana convencional, sendo que o percurso entre Salvador e Feira de Santana (cerca de $110 \mathrm{~km}$ ), superado em cerca de uma hora em dias convencionais, levou cerca de quatro horas na noite do dia 22 de junho. De acordo com dados preliminares da Secretaria de Turismo da Bahia (SETUR-BA), durante o São João deste ano, a cidade de Salvador (tornada agora também, através de projetos como o São João no Pelô, um polo de festejo junino) recebeu cerca de 100 mil turistas, responsáveis por $40 \%$ de ocupação da rede hoteleira soteropolitana, cerca de $1 / 3$ a mais do que a ocupação verificada no mesmo período de 2010. Nessa mesma senda, dados da Secretária da Fazenda do 
Elder P. Maia Alves

Carlos Alexsandro de Carvalho Souza

Estado, apontam um crescimento expressivo da arrecadação do ICMS (Imposto sobre a Circulação de Mercadorias e Serviços) durante o mês de junho nos últimos anos e, por conseguinte, do repasse desse imposto realizado pelo governo do estado aos municípios. Segundo o órgão, o ICMS dos municípios, em 2010, passou de $R \$ 209$ milhões, em maio, para R $\$ 301$ milhões, em junho, representando um aumento de $44 \%$. De acordo com os dados disponibilizados pelas cidades de Salvador, Rio de Janeiro, Recife e São Paulo, em 2012, as quatro cidades geraram, durante o carnaval, cerca de $\mathrm{R} \$ 2,7$ bilhões. Esse montante ultrapassou o orçamento do Ministério da Cultura (MINC) em 2012, que foi de cerca de R\$ 2 bilhões. Em 2013 havia a previsão de que, somente em Salvador, fossem gerados $\mathrm{R} \$ 1,3$ bilhões.

Talvez seja essa uma das razões para que a AMBEV (Companhia de Bebidas das Américas) tenha se tornado a empresa brasileira (ou com grande parte do capital acionário registrado no Brasil) mais valiosa no mundo. De 2011 para 2012 as ações da companhia (negociadas na Bolsa de Valores de São Paulo) obtiveram uma valorização de $27 \%$. Com isso, a companhia de bebidas ultrapassou a PETROBRAS, figurando como a $40^{\circ}$ mais valiosa empresa do mundo, ao passo que a petroleira brasileira figura na $41^{\mathrm{o}}$ colocação $^{18}$. Muitos economistas e analistas examinam esse fato preferindo explorar as razões da queda acionária da PETROBRAS, e não as razões de ascensão da AMBEV. Certamente a contenção do preço dos combustíveis, a competição internacional do petróleo e os dilemas políticos envolvendo a exploração da camada do pré-sal, contribuíram para a significativa perda de mercado da estatal brasileira, mas o que muito pouco se comenta e se aponta são as razões do crescimento da AMBEV. Entre essas razões certamente está a expansão do mercado de cerveja no Brasil, principal produto da AMBEV. Entre 2005 e 2012 a produção de cerveja no Brasil cresceu cerca de 48\%, apresentando uma média de crescimento anual de $6 \%$. Ora, para esse crescimento (48\% em 8 anos) certamente o circuito ampliado de festas populares, shows, carnavais e as atividades de entretenimento noturno contribuíram bastante. De acordo com o Jornal $O$ Valor, as vendas de cervejas e refrigerantes da marca AMBEV, no Brasil, contribuíram para a contínua valorização da companhia. Em 2012, o volume na produção de cerveja, por exemplo, cresceu 4,2\%, já nos demais países da América do Sul onde a companhia atua (Argentina, Uruguai, Bolívia, Chile e Paraguai) registrou-se uma média na produção de 3,2\%, em 2012. Segundo o mesmo veículo, a AMBEV planeja, para 2013, intensificar a difusão das marcas Bohemia, Original, Budweiser e Stella Artois (os produtos premium), nas regiões

${ }^{18}$ http://www1.folha.uol.com.br 


\section{A economia criativa no Brasil: o capitalismo cultural brasileiro contemporâneo.}

Nordeste e Norte do Brasil, como estratagema para a ampliação das vendas e fidelização dos novos consumidores nessas regiões.

A mais contundente política cultural destinada à formação de público e incentivo ao consumo simbólico-cultural das famílias, o Vale Cultura (Lei 5.798), certamente sedimentará a direção aqui explorada. A Lei, em fase de regulamentação, começará a vigi, segundo o MINC, a partir de julho de 2013. O beneficio consiste em destinar $\mathrm{R} \$ 50$ para cada trabalhador brasileiro que recebe até 5 salários mínimos ( $R$ \$ 3.390). Desse montante a empresa arcará com $R \$ 45 \%$ e o trabalhador com $\mathrm{R} \$ 5$. Para tanto, a empresa terá que aderir ao programa, cadastrando-se junto ao Ministério da Cultura e a Receita Federal. O benefício funcionará de modo semelhante a um cartão de carga e descarga, sendo debitado quando os serviços (ingressos, produtos, bens, etc.) forem comprados. Em contra partida, o governo, mediante os dados do MINC e da Receita Federal, deduzira parcelas do imposto de renda das pessoas jurídicas, descontando os impostos devidos pelas empresas que aderirem ao programa. Segundo as expectativas do Ministério da Cultura, espera-se que, nos próximos 5 anos, seja gerada uma receita de R\$ 11bilhões (ou seja, 10\% de todo o PIB da economia criativa, segundo a FIRJAN), beneficiando 19 milhões de trabalhadores. O aspecto mais tenso e hesitante do programa, que está em fase de regulamentação e, logo após, será objeto de uma consulta pública, repousa nos itens que poderão ser objeto de consumo dos trabalhadores. Em recente declaração ${ }^{19}$, a Ministra da Cultura, Marta Suplicy, declarou que, na lista urdida pelo MINC, poderia figurar o serviço de TV por assinatura. Após a declaração, ouviu-se uma grita generalizada dos principais setores das elites culturais e de determinados executivos e empresários da cultura (notadamente do teatro e do cinema), temendo uma concentração dos recursos nos serviços de televisão paga. Após essa reação, a ministra recuou e declarou publicamente ${ }^{20}$ que o Vale Cultura não contemplaria a TV por assinatura. Em outra declaração ${ }^{21}$, a representante máxima do MINC disse que não concordava com a inserção dos games no programa, uma vez que não os considerava cultura. Logo, ouviu-se uma vigorosa reação dos representantes (criadores, empresários, programadores, designs, etc.) da indústria dos gemais no Brasil, aferrados à tarefa de demonstrar o valor cultural dos jogos.

Desde 2008, com o lançamento dos aplicativos para jogos online nos smartphones e tabletes (principalmente aqueles fabricados pela da Apple), o mercado de games vem experimentando um crescimento substancial. Naquele ano, apenas $10 \%$ de todo o consumo e o desenvolvimento dos jogos eram realizados no

${ }^{19}$ Programa Bom dia Ministra, empresa Brasileira de Comunicação (EBC), janeiro de 2013.

${ }^{20}$ http://www1.folha.uol.com.br/ilustrada/

21 http://info.abril.com.br/games/noticias/2013/03/games-nao-sao-cultura-diz-martasuplicy.shtml 
Elder P. Maia Alves

Carlos Alexsandro de Carvalho Souza

ambiente online, ao passo que os jogos das mídias físicas (discos e cartuchos) representavam 51\%, auferindo um faturamento total de US\$ 61 bulhões; em 2010 (quando os jogos incorporaram a dinâmica dos movimentos nas telas dos aparelhos), a fatia de mídia online representava $25 \%$ de todo o mercado, e a física, $41 \%$, com faturamento global de US\$ 66 bilhões; finalmente, em 2012/2013, a mídia online já representa $42 \%$ de todo o desenvolvimento de conteúdos, seguido por $36 \%$ da física, perfazendo, segundo as estimativas, um volume total de US\$78 bilhões. Segundo os dados do IBOPE e de assessorias especializadas ${ }^{22}$, em 2011, o Brasil se tornou o $4^{-}$maior mercado de games do mundo, com 45,2 milhões de jogadores assíduos ou eventuais. A julgar pelo número de 75 milhões de celulares com acesso internet no Brasil e também pelos saltos registrados nas vendas de tablets e smartphones (crescimento de $267 \%$ para o primeiro e $55 \%$ para o segundo, em 2012), o Brasil sé manterá entre os cinco maiores mercados de games do mundo. Em face desses dados, as empresas do setor de conteúdos de games mobilizam não só os recursos criativos, com o também as energias políticas para, por exemplo, alterar a legislação brasileira, que trata os games como jogo de azar e, portanto, sujeito a uma tributação muito maior por conta desse aspecto. Os investimentos criativos e o aprimoramento das empresas de desenvolvimento de conteúdos têm levado muitos governos europeus, entidades especializadas, críticos e artistas a tratarem a linguagem gráfica dos jogos como criação artística, estabelecendo premiações específicas e novas formas de classificação advindas do design gráfico e das arquiteturas digitais criadas para ambientar os jogos. Como se pode depreender, o Vale Cultura afeta o cerne do aspecto mais espinhoso de todo o debate político, institucional e conceitual envolvendo a tradução do tema da economia criativa no Brasil, que pode ser sintetizado na seguinte indagação: por que e como determinadas linguagens e setores tem sido chanceladas como criativos (e, logo, dignos da deferência de cultural) em detrimento de outros?

\section{Economia criativa para o desenvolvimento: criatividade, diversidade e marcas da brasilidade.}

No âmbito das organizações governamentais de cultura (ministério, secretarias, fundações, etc.) uma nova asserção parece se constituir como uma espécie de lei de ferro no âmbito da agenda política contemporânea: o desenvolvimento brasileiro (ou neo-desenvolvimento) e, em grande medida, o desenvolvimento latino-americano, passa, inexoravelmente, pela produção simbólico-cultural. Ou seja, pela capacidade de geração de oportunidade de trabalho, emprego e renda e, por conseguinte, inclusão econômico-social, que a expansão dos distintos mercados culturais (e os seus nichos e sub-nichos) pode

${ }^{22}$ Revista Exame, 3/4/2013.

Latitude, vol. 6, n², pp.06-21, 2012 


\section{A economia criativa no Brasil: o capitalismo cultural brasileiro contemporâneo.}

vicejar. Esse consenso vem sendo urdido no seio das principais organizações da administração pública latino-americana e tem como catalisador central a categoria teórico-prática de economia criativa. O conceito de economia criativa responde, assim, pelo centro gravitacional de uma nova família conceitual que tem acionado novas tecnologias sociais de empreendedorismo e o fomento inédito de novos modelos de negócios culturais, escorados numa nova hierarquia ético-estética da criatividade. Esse consenso, no entanto, é bastante recente.

Em janeiro de 2011 o Ministério da Cultura criou a Secretaria da Economia Criativa (SEC); em julho do mesmo ano o Ministério da Ciência, Tecnologia e Inovação (MCTI), mediante o Conselho Nacional de Desenvolvimento Científico e Tecnológico $(\mathrm{CNPq})$, criou o programa Ciência sem fronteira, que destinará $75 \mathrm{mil}$ bolsas de estudos nos próximos anos, alcançando um investimento total de $\mathrm{R} \$ 3,16$ bilhões, distribuídos por dezoito áreas consideradas estratégicas, entre elas as indústrias criativas; Em 2011 o Banco Santander criou um prêmio universitário destinado à economia criativa, no ano seguinte foi criado, no âmbito do Congresso Nacional, a Frente Parlamentar em defesa da Economia Criativa. Em dezembro de 2011 foi lançado, pela Secretaria da Economia Criativa (SEC), o Edital Brasil Criativo, que, junto com a ação de criação dos Birôs Criativos, busca assessorar e criar as condições para o funcionamento de médias e pequenas empresas criativas, localizadas nos chamados setores criativos. O Edital de Fomento a Iniciativas Empreendedoras e Inovadoras foi destinado à identificação, reconhecimento, fomento e difusão das iniciativas empreendedoras e inovadoras da sociedade civil atuantes nos setores criativos. Foram premiadas 150 iniciativas selecionadas nas seguintes categorias: novos modelos de gestão de empreendimentos e negócios criativos e formação para competências criativas. A premiação foi de $\mathrm{R} \$ 3,6$ milhões. Já o segundo edital, Edital de Apoio à Pesquisa em Economia Criativa selecionou estudos e pesquisas acerca de temas da economia criativa nos contextos macroeconômico e legal-institucional brasileiro. Foram laureadas 22 pesquisas. O apoio destinou-se a pesquisadores da área acadêmica com atuação na área da pesquisa. A premiação correspondeu a $\mathrm{R} \$ 810$ mil reais divididos em três categorias: Teses de Doutorado; dissertações de mestrado e Produção em grupo de pesquisa. Os trabalhos vencedores estão hospedados, hoje, para consulta pública, no sitio do Observatório Brasileiro da Economia Criativa (OBEC), espécie de braço de profusão das pesquisas acadêmicas e dos eventos envolvendo o tema no Brasil. Já a ação de fomento dos Birôs Criativos destina-se a criação de centros de apoio para os agentes culturais, prestando assessoria para a elaboração de modelos de negócios, planos de comunicação e distribuição, consultoria jurídica, linhas de crédito e mecanismos de exportação específicos para o setor cultural. Com um investimento de $\mathrm{R} \$ 1,5$ milhão o primeiro Creativa Birô foi implementado no Estado de Pernambuco, segundo o Ministério da Cultura, outros quatro projetos pilotos estão sendo implementados, um em cada região do país. O objetivo, segundo o próprio ministério, é levar os 
Elder P. Maia Alves

Carlos Alexsandro de Carvalho Souza

Criativa Birô para todos os estados da federação. Em março de 2013 foi lançado o Edital de Contratação de Serviços Técnicos Especializados, no âmbito do Programa de Capacitação em Gestão de Projetos e Empreendimentos Criativos, coordenado pela Secretaria de Incentivo e Fomento à Cultura (SEFC) em Parceria com a Secretaria da Economia Criativa (SEC), com vistas a contratar uma instituição federal capaz de capacitar um grande número de gestores e profissionais criativos.

Essas ações derivaram do Plano da Secretaria da Economia Criativa (SEC), lançado oficialmente pela Secretária Cláudia Leitão, em setembro de 2011, na Fundação Casa de Rui Barbosa (FCRB), no Rio de Janeiro. O plano é um documento minucioso, que arrola, além da definição de economia criativa, sua justificativa, operacionalidade, objetivo, o processo de criação do plano, as etapas e fases de implementação e os diversos parceiros envolvidos, que se dividem em quatro grandes grupos: linhas de crédito (BNDES, Banco do Nordeste, Banco do Brasil, Caixa Econômica Federal e Banco da Amazônia); políticas públicas de fomento (Petrobrás, Correios, Eletrobrás, Chesf e Furnas); estudos e pesquisas (IPEA, IBGE, Fundações de Amparo à Pesquisa, Capes e CNPq); formação, empreendimentos e difusão (SEBRAE, SESCOOP, SEST, SENAT, SESC, SENAC, SESI e SENAI) e formação, gestão e fomento (OEI, UNITAR, UNESCO e UNCTAD). Segundo o plano, existem cinco campos na economia criativa brasileira, que abarcam vinte setores específicos. 
A economia criativa no Brasil: o capitalismo cultural brasileiro contemporâneo.

FIGURA 5: Escopo dos Setores Criativos Ministério da Cultura (2011)

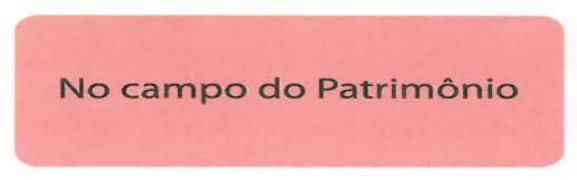

Patrimônio material

. Patrimônio Imaterial

- Arquivos

- Museus

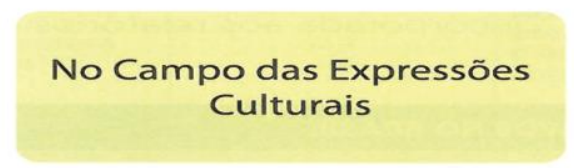

- Artesanato

Culturas populares

Culturas indígenas

- Culturas afro-brasileiras

. Artes visuais

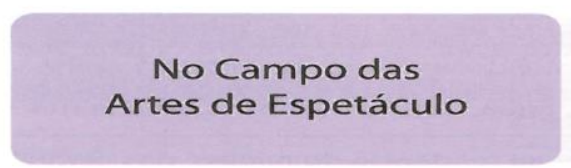

Dança

Música

Circo

Teatro

\section{No Campo do Audiovisual e do Livro, da Leitura e da Literatura}

Cinema e Vídeo - Publicações e Mídias Impressas

No Campo das

Moda

Design

Criações Funcionais

- Arquitetura

Arte Digital

Fonte: SEC/Minc

A figura 5, que traz o escopo dos setores criativos da SEC/MINC, exige que se percorra e se coteje a concepção de criatividade, desenvolvimento e cultura cultivadas e institucionalizadas pelo MINC. No texto de abertura do Plano da Secretaria da Economia criativa, intitulado A criatividade e a diversidade cultural brasileira como novo recurso para um novo desenvolvimento, a secretaria Cláudia Leitão indaga: "como transformar um esforço desesperado de cultura em um direito fundamental ao desenvolvimento"? As relações entre criatividade, cultura $e$ desenvolvimento, tornadas ações, projetos e políticas pelo MINC, estabeleceram os principais estético-normativos que guiaram o Plano da Secretaria da Economia Criativa e a feitura da figura 4. Os conceitos de cultura e desenvolvimento têm objeto de uma grande dilatação conceitual nas últimas décadas, expandindo seus campos de significação, justificação e operacionalização político-econômica. Essas dilatações foram realizadas no âmbito de intensa expansão do processo de industrialização do simbólico e digitalização do simbólico e do crescimento da 
Elder P. Maia Alves

Carlos Alexsandro de Carvalho Souza

importância econômica dos serviços e bens culturais a partir dos anos 70 . O alargamento do conceito de cultura operou no sentido de incorporar a noção de cultura como experiência vivida e saber não formal acumulado, valorizando as noções de transmissão oral e patrimônio imaterial, internalizadas e transmitidas nas práticas cotidianas, mas também passou a deposita grande relevo na noção de cultura enquanto produção, inserida em um mercado especifico de consecução, circulação e fruição de bens e serviços culturais. No desenho geral dos programas e ações do Ministério da Cultura, a maioria dos programas e ações justifica-se a partir de uma determinada dimensão do conceito de cultura. A matriz básica de fundamentação teórica do Plano Nacional de Cultura (PNC, Lei no 12.343 , de 2 de dezembro de 2010) e do Sistema Nacional de Cultura (SNC, Emenda Constitucional $n^{\circ} 71 / 2012$, que acrescentou o artigo 216-A à Constituição Federal) diz respeito à tríade conceitual que envolve o conceito de cultura aclimatada pelo Ministério da Cultura desde 2003.

A cultura, de acordo com o PNC/SNCMINC, deve ser pensada na sua dimensão simbólica, econômica e cidadã. Essas três dimensões aparecem de maneira combinada, tanto nas justificativas teóricas, quantos nos programas e ações desenvolvidas. A dimensão simbólica decorre do imperativo de se valorizar e, por conseguinte, consolidar a identidade nacional. Por outro lado, a dimensão simbólica repousa no imperativo de criar as condições de fruição e experimentação cultural, ou seja, o direito de adquirir e pertencer à outra cultura, mediante o consumo de bens e serviços culturais. A dimensão econômica traça interfaces estreitas com a dimensão simbólica, pode ser sintetizada a partir do entendimento de que a riqueza simbólica também deve ser acompanhada da possibilidade de criação de riqueza material para os criadores e realizadores culturais, através da geração de trabalho, emprego e renda. Já a dimensão cidadã abriga as outras duas. A rigor, a sua postulação supõe a realização das duas dimensões anteriores. A dimensão cidadã trata da necessidade imperativa, segundo os gestores do sistema MINC, de acionar e cristalizar os direitos culturais no Brasil, estabelecidos desde a constituição de 1988, nos artigos 215 e 216.

O tema e o conceito de economia criativa se inserem na dimensão econômica dessa tríade conceitual-institucional, substituindo a antiga e evasiva noção de economia da cultura, que, até 2010, respondia pela dimensão econômica no interior do arranjo político-institucional do MINC. O conceito, por conseguinte, passa a estar presente a municiar as ações dos dois principais mecanismos legais de gestão e implementação das políticas culturais no Brasil: o Plano Nacional de Cultura (Lei no 12.343, de 2 de dezembro de 2010) e o Sistema Nacional de Cultura (Emenda Constitucional $\mathrm{n}^{\circ}$ 71/2012). No primeiro, o tema da economia criativa está diretamente presente nas metas do plano, figurando entre a meta 7 e 11 (100\% dos segmentos culturais com cadeias produtivas da economia criativa mapeadas; 110 territórios criativos reconhecidos; 300 projetos de apoio à sustentabilidade 


\section{A economia criativa no Brasil: o capitalismo cultural brasileiro contemporâneo.}

econômica da produção cultural local e Aumento em 15\% do impacto dos aspectos culturais na média nacional de competitividade dos destinos turísticos brasileiros). Já no segundo instrumento, o SNC, o tema da economia criativa se insere mediante a presença no Plano Nacional de Cultura, pois este é o operador do Sistema. Uma das componentes do Sistema Nacional de Cultura (SNC) é a feitura e implementação de Planos Estaduais e Municipais de Cultura (meta numero 1 do PNC: Sistema Nacional de Cultura institucionalizado e implementado, com $100 \%$ das Unidades da Federação (UF) e 60\% dos municípios com sistemas de cultura institucionalizados e implementados). Para tanto, o MINC vem coordenando um amplo processo de pactuação institucional, no qual, a partir da adesão ao sistema, estados e municípios recebem assessoria técnica para criar e implementar os seus sistemas, que, além dos planos estaduais e municipais (ou seja, os conteúdos políticos e normativos dos projetos e ações, como o tema da economia criativa) contém: Órgão gestor de cultura; conferência de cultura; Conselho de política cultural; Sistema de financiamento à cultura; Comissão Inter gestores; Programa de Fomento na área da cultura; Sistema de informação e indicadores culturais e Sistema setoriais de cultura). Até abril de 2013, 23 estados e 1.752 municípios haviam formalizados a sua adesão ao Sistema Nacional de Cultura (SNC). É principalmente por meios desse arranjo jurídico-politico que o tema da economia criativa tem ganhado densidade empírica no âmbito da administração cultural pública brasileira, grassado pelas administrações culturais públicas dos estados e municípios.

Concomitante a dilatação conceitual experimentada pelo conceito de cultura, o conceito de desenvolvimento, desde o final dos anos 70 do século passado, também vem se dilatando. A noção de desenvolvimento sofreu um deslocamento em duas direções. Por um lado, seu conteúdo econômico é atenuado, isto é, os antigos índices macroeconômicos são revistos a partir de sua relação com as condições de vida das populações mais pobres, que permaneciam à revelia dos ganhos econômicos e do crescimento da economia. Assim, os critérios macroeconômicos são substituídos por índices que buscam aferir e avaliar até que ponto e em que medida o crescimento econômico e o desenvolvimento estão melhorando a vida de determinados países e, sobretudo, de suas populações mais pobres. O conceito de desenvolvimento, seguindo essa direção, passa a ser objeto de uma revisão e uma crítica que o desloca, para uma racionalização discursiva e prática que se inscreve em uma moralidade mais ampla, aquela que vê o desenvolvimento econômico apenas como uma dimensão do desenvolvimento humano; ou seja, como o respeito à dimensão cultural (pensada no sentido antropológico), sintonizado às especificidades culturais no processo de desenvolvimento (cultura no desenvolvimento), e a cultura como vetor de expansão da renda, do crédito e das potencialidades empreendedoras (a cultura para o desenvolvimento). A relação entre as categorias de cultura e desenvolvimento ocupa um lugar de destaque no 
percurso de compreensão do processo de institucionalização do tema da economia criativa como política cultural especifica, pois permite localizar os efeitos práticos (jurídicos, políticos e econômicos) do processo de dilatação conceitual dos núcleos de significados das categorias de cultura e desenvolvimento.

Figura 6. Dimensões das categorias de cultura e desenvolvimento no âmbito do Sistema Nacional de Cultura (SNC) e do Plano Nacional de Cultura (PNC).

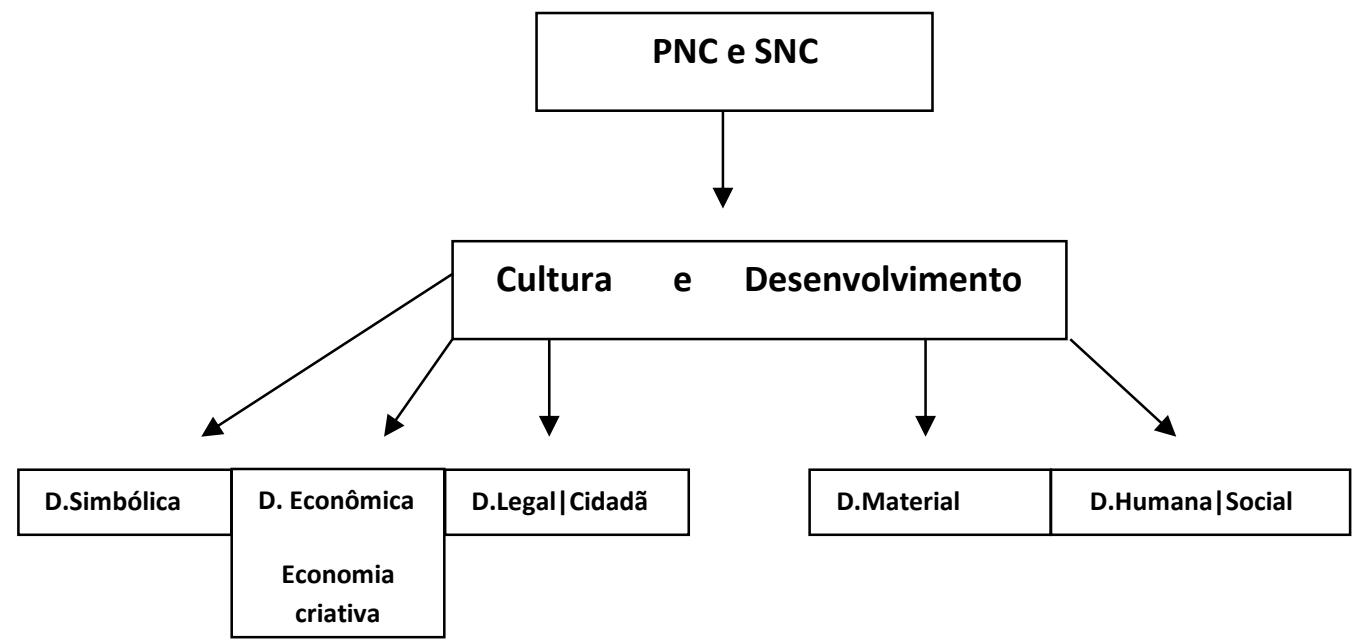

Fonte: o autor.

De acordo com o Plano da Secretaria da Economia Criativa (SEC), a feitura do plano, a consecução do projeto que resultou na criação da secretaria e o teor conceitual da economia criativa preconizado pela SEC/MINC, foram norteados por quatro princípios: inclusão social; diversidade cultural; inovação e sustentabilidade. Esses princípios orientaram (não sem tensões, pressões e hesitações) as escolhas dos campos criativos delineados na figura 5 e atravessam toda extensão do documento supracitado. O primeiro princípio (inclusão) gravita nas politicas formuladas pelo MINC desde 2003, respondendo pelo objetivo maior da dimensão econômica do conceito de cultura. A inclusão social é, sobretudo, a chave mais geral par a inclusão econômica, cuja face mais visível responde pelas políticas e os processos de qualificação e profissionalização artístico-culturais demandados pela expansão do consumo dos bens simbólico-culturais, principalmente os bens e serviços que derivam dos saberes, dos fazeres e das expressões da chamada cultura popular tradicional, que, de acordo com lógicas especificas, legitimam e chancelam os bens 


\section{A economia criativa no Brasil: o capitalismo cultural brasileiro contemporâneo.}

da "tradição" e da "autenticidade" (ALVES, 2011). Nesses termos, para a SEC/MINC, incluir significa criar as condições de circulação e inserção de serviços, atividades e bens criativos que, a partir da consecução de redes ampliadas de negócios e empreendimentos, fomente trabalho, emprego e renda. Esse princípio atua mais como um meta-princípio, pois desvela um dos objetivos centrais das políticas culturais orientadas pelo tema/conceito da economia criativa: ampliar as oportunidades e o número dos trabalhadores culturais. Esse desiderato se torna premente em face do crescimento do contingente de trabalhadores culturais no Brasil. De acordo com Frederico Barbosa ${ }^{23}$, o número de indivíduos que exerciam empregos culturais em 2002 era de 1,5 milhões, ao passo que, em 2008, já era de 2 milhões, representando, em 6 anos, um crescimento de 33\%, que significou, segundo o autor, uma variação liquida positiva de 432,8 mil ocupações. Nessa frente, verificou, cotejando-se a dinâmica geral de crescimento do mercado de trabalho no Brasil, entre 2002 e 2008, que o trabalho cultural apresentou uma dinâmica de crescimento acima da média dos outros mercados, $27 \%$, ao passo que o conjunto auferiu uma média de $17 \%$, durante o intervalo supracitado.

O segundo princípio, a diversidade cultural, é o grande principio mobilizador, não só porque aciona práticas, políticas e ações com vistas à manutenção e profusão da diversidade, mas porque catalisa dois aspectos centrais: 1) por um lado, trata-se de um princípio ético-estético que goza de grande reconhecimento e legitimidade em diversos grupos, organizações e instituições nacionais e transnacionais, que, em uníssono, cerram fileiras em nome da diversidade cultural (que costuma condensar também as demais diversidades: sexual, étnica, ambiental, etc.), figurando, assim, como a principal justificativa para a implementação das políticas culturais para a economia criativa, que buscam, com efeito, proteger e fomentar a diversidade cultural; 2) por outro lado, trata-se de um princípio-meio, pois, em todas as falas institucionais e governamentais, a diversidade é percebida como o principal recurso simbólico da economia criativa brasileira; ou seja, como um manancial vibrante e fecundo, preenche das mais variadas possibilidades criativas. Essa justificativa-meio se acha espraiada por um circuito transnacional, que envolve a atuação de diversos agentes, como as coalizões globais de luta em defesa e promoção da identidade e da diversidade cultural, a UNESCO, os governos nacionais, grupos de artistas e intelectuais, Organizações Não-Governamentais (ONGs), entre outros. O primeiro aspecto deriva da construção de um processo político-cultural que remonta aos anos 80 e 90 do século XX.

O crescimento dos mercados culturais mundiais e a expansão dos fluxos simbólicos globais geraram a sensação generalizada de que o mundo estaria passando por um processo acelerado de homogeneização e padronização cultural

${ }^{23}$ Verificar o artigo publicado neste dossiê. Desenvolvimento e cultura: linhas gerais para um mapeamento conceitual e empírico. 
Elder P. Maia Alves

Carlos Alexsandro de Carvalho Souza

(MATTELART, 2005). Essa sensação decorreu, em certa medida, das profundas assimetrias existentes entre os principais pólos de produção simbólica (Estados Unidos e União Européia), classificados como os centros exportadores de bens culturais, e os pólos de consumo (América Latina, África e Ásia), classificados como os centros de importação. A globalização cultural estaria, assim, potencializando as antigas e já profundas assimetrias da divisão internacional do trabalho cultural (YÚDICE, 2005). É em nome da preservação e promoção da diversidade e da identidade cultural que muitos governos, empresas de cultura e instituições transnacionais passaram a defender a elaboração e execução de novas políticas públicas de cultura. Essas mobilizações culminaram na aprovação da Convenção Sobre a Proteção e a Promoção da Diversidade das Expressões Culturais, 2005, e a Convenção para Salvaguarda do Patrimônio Cultural Imaterial, 2003. Esses documentos são resultado de um longo processo de normatização, oficialização e dilatação do conceito de cultura no âmbito da UNESCO, desencadeado com maior vigor a partir dos anos 70 e recrudescido nos anos 90 a partir das demandas políticas, econômicas e simbólicas que surgiram nas últimas décadas do século XX. São exemplos desses processos de normatização as conferências de cultura realizadas pela UNESCO ao longo da década de 70 e 80, a saber, a EUROCULT, realizada em Helsinque, em 1972; a ASIACULT, realizada em Jacarta, em 1973; a AFRICACULT, realizada em Accra; a AMERICACULT, realizada em Bogotá, em 1978 e ARABIACULT, realizada em Bagdá, em 1981, todas culminando na Conferência Mundial sobre Políticas Culturais (MUNDIALCULT), realizada na Cidade do México, em 1982, e atualizada na Conferência de Estocolmo sobre Políticas Culturais para o Desenvolvimento, em 1988.

Bastante curioso é que, por contraditório que possa parecer, a ameaça de padronização das expressões artístico-culturais trazidas pela globalização cultural e, com efeito, pelos grande conglomerados transnacionais de cultura e comunicação, criaram as condições para a emergência e institucionalização de um apelo global em defesa da diversidade, traduzido na aprovação das duas convenções da UNESCO/ONU: Convenção Sobre a Proteção e a Promoção da Diversidade das Expressões Culturais, 2005, e a Convenção para Salvaguarda do Patrimônio Cultural Imaterial, 2003. Ainda mais curioso, mas não menos inteligível, é o fato de que a partir da década passada, muito em razão das transformações envolvendo arte, técnica e mercado, as criticas políticas e culturais às empresas e conglomerados de cultura e comunicação e também ao conceito de indústria cultural passaram a ser, paulatinamente, suavizadas no ambiente da UNESCO. Ao ponto de hoje (como acontece com a UNCTAD) o conceito de indústria cultural ser utilizado no sentido mais formal, solene e descritível possível, designando também criação e diversidade. Por exemplo, por ocasião do Lançamento do Edital do Fundo Mundial Para Diversidade (gerido financeiramente pela UNESCO e criado pela Convenção Sobre a Proteção e a Promoção da Diversidade das Expressões Culturais), a chamada do edital 


\section{A economia criativa no Brasil: o capitalismo cultural brasileiro contemporâneo.}

diz que o fundo tem como objetivo apoiar projetos e programas em desenvolvimento, "no que se refere à implementação de políticas culturais e ao fortalecimento da infraestrutura institucionais correspondentes; aos fortalecimento das capacidades culturais; ao fortalecimento das indústrias culturais existentes; à criação de novas indústrias culturais; e à proteção de expressões culturais comprovadamente em risco de extinção" (UNESCO, 2013).

A diversidade passou a ser um valor mobilizador, capaz de catalisar e unificar a atuação político-culturais de diversas instituições e movimentos em todo o mundo, cujo significado só exige e instaura, de imediato, a relação da diversidade com a chamada Cultura popular tradicional e/ou o patrimônio imaterial. Essa três categorias passaram a figurar, tanto nos documentos e tratados internacionais quanto nos relatórios de avaliação e gestão das políticas culturais nacionais, como as principais fontes da diversidade cultural. Essas categorias/princípios/valores (cultura popular, patrimônio imaterial e tradição) tornaram-se, por um lado, recurso para se falar e justificar o tema/valor da diversidade; por outro, converteram-se em objeto de proteção e promoção, necessário à manutenção e expansão da diversidade (UNESCO, 2005). Logo no segundo ponto de justificação da Convenção para Salvaguarda do Patrimônio Cultural Imaterial aparece a seguinte introdução, utilizada para justificar os parágrafos seguintes: "considerando a importância do patrimônio imaterial cultural como fonte da diversidade cultural e garantia de desenvolvimento sustentável, conforme destacado na Recomendação da UNESCO sobre a Salvaguarda da Cultura Tradicional e Popular, de 1989, como na Declaração Universal da UNESCO sobre a diversidade Cultural, de 2001, e na Declaração de Istambul, de 2002, aprovada pela Terceira Mesa Redonda de Ministros da Cultura" (UNESCO, 2003).

$\mathrm{O}$ conceito de diversidade cultural não apenas se espalha e continua a inspirar políticas públicas atinentes às indústrias da cultura, mas sua audiência cresce desde o início do novo milênio e mostra que ele as transcende e tende a se tornar uma referência maior na busca de um novo ordenamento do planeta. As agências do sistema das Nações Unidas trazem-no para sua ordem do dia. As associações profissionais e os movimentos sociais se mobilizam em seu nome (MATTELART, 2005).

O princípio da diversidade cultural, ou seja, a sua proteção, promoção e difusão encontrou acolhida institucional, no Brasil, por meio da criação da Secretaria da Diversidade e da Identidade Cultural (SID), em 2004, hoje Secretaria da Cidadania Cultural do MINC, mas encontra grande ressonância prática e legitimidade estético-econômica na Secretaria da Economia Criativa (SEC), no Plano Nacional de Cultura (metas 3, 4, 5 e 6), no Sistema Nacional de Cultura e na Lei 12.485 (Lei da TV por assinatura). O segundo aspecto pontuado acima, que torna a diversidade um princípio-meio para o Plano da SEC (a diversidade como o principal recurso simbólico-material da economia criativa brasileira), figura como 
uma meta-justificativa estético-econômica, presente nas falas e ações de executivos e empresários da cultura; de empresas e organizações de entretenimento; de presidentes de bancos de fomento; de entidades de capacitação e apoio; órgãos de pesquisa, institutos e universidades; profissionais do design; da moda; da arquitetura; da publicidade; da televisão; da canção popular; do cinema; da gastronomia, etc. A rigor, esses agentes apontam a chamada cultura popular tradicional (também justaposta ao patrimônio imaterial) como o substrato e o grande reservatório da diversidade cultural, engendrando o amálgama diversidade/tradição/imaterialidade, ou conformando um sistema de homologias entre as categorias teórico-práticas de desenvolvimento, cultura, criatividade, diversidade, imaterialidade, autenticidade e tradição. Talvez um trecho de um dos textos de apresentação do Plano da SEC, de autoria do Presidente do BNDES, Luciano Coutinho, expresse tais homologias.

Hoje se reconhece que quanto mais denso, diverso e rico o conteúdo cultural de uma sociedade, maiores as suas possibilidades de desenvolvimento. $\mathrm{O}$ vigor das manifestações culturais mais enraizadas permite sua preservação e difusão e pode representar uma significativa alternativa de inclusão produtiva, seja pelas oportunidades de criação de emprego e renda, seja pela ampliação do acesso e da qualificação desses serviços. Em consonância com o Plano Brasil sem Miséria, destaque-se, ainda, a capacidade de estimular o desenvolvimento de outras atividades produtivas associadas às atividades culturais. Esses atributos são particularmente importantes em países como o Brasil, de vasta riqueza e diversidade natural, patrimonial e cultural, fruto de um território de dimensões continentais e da fusão de múltiplas etnias (COUTINHO, 2011).

Figura 7. Trânsito relacional entre os princípios ético-estéticos norteadores do Plano da Secretaria da Economia Criativa (SEC/MINC).

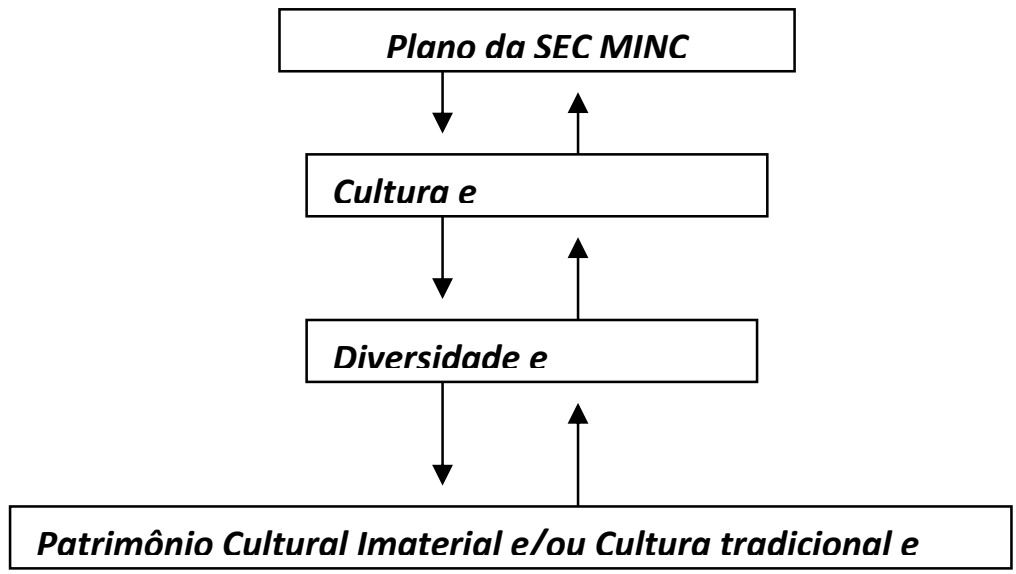

Fonte: o Autor. 


\section{A economia criativa no Brasil: o capitalismo cultural brasileiro contemporâneo.}

O terceiro princípio normativo presente no Plano da SEC/MIN, a sustentabilidade, também vem, paulatinamente, integrando o circuito relacional expresso pela figura 6. Como assinala Mattelart, o tema da diversidade cultural vem sendo também filtrado e associado como um complemento ao registro da diversidade biológica. Ao longo dos anos 90 os temas da diversidade cultural e natural passaram a integrar o mesmo repertório discursivo acionado e manejado pela UNESCO. A aproximação dessas grades temáticas aparece, por exemplo, na Conferência Intergovernamental sobre Políticas Culturais para o Desenvolvimento, realizada em Estocolmo no ano de 1988, onde a organização defendeu um equilíbrio entre os ecossistemas culturais tal qual ocorre entre os ecossistemas naturais. Na Conferência Geral que promulgou a Declaração Universal sobe a Diversidade Cultural, em 2001, a UNESCO declarou ser a diversidade cultural tão vital para o gênero humano quanto a biodiversidade o é na ordem dos seres vivos (UNESCO, 2003). Ainda em 1972, segundo Mattelart, durante a Conferência das Nações Unidas sobre o Meio Ambiente e o Desenvolvimento, em Estocolmo: "se associou o tema da defesa da biodiversidade ao da diversidade cultural, todas duas realidades ameaçadas pelas lógicas predatórias e desiguais do modelo de crescimento ocidental, impulsionado pelo consumo excessivo de recursos naturais como bens materiais" (MATTELART, 2005).

O último princípio da inovação, por fim, corresponde a face conceitual de formação e investimento nas tecnologias sociais do empreendedorismo e da inovação, muito tributárias, no âmbito da experimentação artística, das aproximações histórico-estruturais entre arte, tecnologia e entretenimento. Esse aspecto pode ser contatado mediante os convênios firmados entre a SEC e o SEBRAE nacional. O tema/conceito da economia criativa vem sendo incorporado ao ambiente técnico do SEBRAE desde 2011, e já conta com 143 projetos em andamento. Em 2002, em parceria com a SEC, o SEBRAE criou o Movimento Festival HotSpot, que consiste em atrair ideias e projetos para a realização do festival da criatividade, que irá percorrer 10 cidades brasileiras em 2013 e 2014. Para tanto, foram selecionados 305 projetos em todo o país, que integrarão a agenda do festival nos seguintes segmentos: fotografia, filme, arquitetura, design gráfico, ilustração, cenografia, beleza, moda, design e música. Conforme o Plano da SEC/MINC, a inovação aplicada e cultivada pela cultura exige um ruptura permanente com as regras de mercado estabelecidas: "assumir a economia criativa como vetor de desenvolvimento, como processo cultural gerador de inovação, é assumi-la em sua dimensão dialógica, ou seja, de um lado como resposta as demandas de mercado, de outro, como rompimento às mesmas" (SEC/MINC, 2011). Como se vê, há no registro de justificação conceitual da inovação uma teoria nativa acerca da realização da inovação diante das interfaces entre cultura e mercado, e, de resto, essa teoria se exprime em outros trechos do documento supracitado: 
Elder P. Maia Alves

Carlos Alexsandro de Carvalho Souza

Nossa compreensão de economia criativa definitivamente não se submete ao significado moderno das "indústrias culturais". Pelo contrário, o grande desafio intelectual e político para construção do Plano da Secretaria era o de retomar o papel do MINC na formulação de políticas públicas para o desenvolvimento brasileiro. Por isso, nossa primeira tarefa foi de pactuar os fundamentos da economia criativa a partir dos seguintes princípios: inclusão social, sustentabilidade, inovação e diversidade cultural brasileira.

[...] Todas essas considerações vão iluminando as distinções entre a indústria cultural e as novas configurações institucionais da indústria criativa $e$ economia criativa: não temas mais o modelo (predominantemente) das grandes empresas, mas sim pequenos negócios de produtores autônomos tanto nas comunicações como na moda, no design gráfico e de produto, na publicidade alternativa, no audiovisual, etc. e o ideal, do ponto de vista do planejamento urbano e das cidades criativas é a reunião desses pequenos negócios em clusters que alimenta a 'diversidade', a 'riqueza' e a 'criatividade' urbanas. Da mesma maneira enquanto a indústria cultural parece se reportar a um componente coletivo abstrato de cultura, na indústria criativa o apelo constante é à criatividade individual (SEC/MINC, 2011).

Como se pode constatar, diferente da FIRJAN, da UNCTAD, da UNESCO e também do SEBRAE, a SEC/MINC mantém e atualiza a crítica político-cultural às chamadas indústrias culturais, arregimentadas e difundida pelas esquerdas latinoamericanas durante os anos 60 e 70 . Depreende-se, assim, dos excertos acima, que as escolha dos quatro princípios supracitados deveu-se a necessidade de não se submeter ao significado moderno das indústrias culturais, nesse caso potencialmente não inclusivas, não inovadoras, não afeitas à diversidade e à sustentabilidade. Certamente decorre desses aspectos a não inclusão expressa da televisão e da publicidade nos segmentos criativos e, mais especificamente, no campo do audiovisual, como delineia a figura 5. Ao mesmo tempo, o documento da SEC/MINC estabelece as diferenças fundamentais entre a indústria cultural e a indústria criativa, atribuindo a distinção central ao modelo empresarial das companhias da indústria cultural, que se reportava a aspectos abstratos da cultura, ao passo que as indústrias criativas retiram seu substrato direto da criatividade 


\section{A economia criativa no Brasil: o capitalismo cultural brasileiro contemporâneo.}

individual. Essa definição nativa acerca dos processos criativos na indústria cultural e nas indústrias criativas expressam bem os delicados e complexos equilíbrios de um agente governamental diante dos meandros sinuosos dos mercados culturais e das relações entre o domínio estético-expressivo e o domínio econômico-comercial no mundo contemporâneo, pois, ao mesmo tempo em que a SEC/MINC faz restrições à indústria cultural, incorpora em seus esquemas e modelos (figura 5) poderosos interesses comercias e estéticos, como os do design, da moda e dos jogos eletrônicos, tributários das pressões e do crescimento econômico-simbólico das grandes empresas e corporações diretamente ligadas a esses segmentos, como aquelas que a FIRJAN, a FECOMÉRCIO e a FIESP representam.

Cada um dos princípios esposados pelo Plano da SEC concorreu, em maior ou menor grau, para a incorporação de novos setores criativos (expressos na figura 5) e, por conseguinte, para a inserção de novos segmentos nas políticas culturais formuladas e geridas pelo MINC (como a Lei Rouanet, os projetos do Fundo Nacional de Cultura e os colegiados setoriais). Como a UNCTAD e a FIRJAN, a SEC/MINC não estabelece uma hierarquia entre os segmentos e setores, embora, como se viu, exclua a televisão e a publicidade (ou a "grande televisão e a "grande" publicidade"), incorporando, todavia, o campo das criações funcionais: arquitetura, moda, design e arte digital. Ora, por que incorporar esses três últimos segmentos, até pouco tempo considerados apenas funcionais, ou seja, como tributários das funções designadas pelas indústrias (cadeiras, roupas, aplicativos e programas digitais)? Certamente essa incorporação de deu em razão da especificidade da tradução do conceito/tema de economia criativa no Brasil, que expõe quatro aspectos: 1) o reconhecimento da presença dos processos criativos nesses segmentos; 2 ) os usos estéticos e políticos do princípio da diversidade cultural por parte desses segmentos; 3) a pressão político-cultural exercida por tais segmentos e 4) a pujança econômica assumida pelos mesmos nos últimos anos.

Mais do que figurarem no campo das criações funcionais da SEC/MINC, os segmentos da moda, design, cultura digital (ou arte digital) e também gastronomia buscam a sua inserção junto aos mecanismos de renúncia previstos na Lei Rouanet e nos diversos projetos apreciados pelo Conselho Nacional de Políticas Culturais (CNPC). Essa inserção, com efeito, se deve ao cruzamento dos 4 aspectos apontados acima. De acordo com a FIRJAN, a cadeia criativa da moda brasileira corresponde a $30 \%$ do total de estabelecimentos e empresas presentes em toda cadeia produtiva (núcleo, atividades relacionadas e apoio) das indústrias criativas no Brasil. Essa mesma cadeia emprega, no total, 1,2 milhão de trabalhadores, desde designs de roupas e sapatos até os vendedores e estilistas. De acordo com o estudo Economia e cultura da moda no Brasil: um estudo para politicas públicas, realizado em parceria com o Conselho Nacional de Políticas Culturais, a Secretaria Executiva e a Secretaria de Políticas Culturais do Ministério da Cultura, a grande potencialidade da moda brasileira é o valor cultural local. Desde a década passada que os principais 
Elder P. Maia Alves

Carlos Alexsandro de Carvalho Souza

agentes da moda brasileira (estilistas, marcas, distribuidores, representantes da indústria têxtil, segmentos varejistas, etc.) tem buscado ancorar suas criações (o norte conceitual das criações para os eventos e os desfiles que marcam as estações) nas expressões artístico-culturais da cultura popular brasileira. Peças inspiradas nos desenhos e estampas dos mestres e mestras do Tambor de Criola do Maranhão; chinelos e sapatos, além de adereços da moda masculina e feminina, inspiradas nas vestimentas dos cangaceiros; moda e tendências inspiradas nas rendas e bordados da tradicional figura das baianas, dentre outros exemplos, tem se tornando uma regularidade das marcas brasileiras que se apresentam nos dois maiores eventos de moda do país: São Paulo Fashion Week e Fashion Rio. Essa recorrência encontra eco no discurso e nos processos criativos dos estilistas (ou "conceitualistas", que, em face dos investimentos discursivos para o reconhecimento da moda como arte, tornam-se, cada vez mais, "estilistas culturalistas") que apontam, sem hesitar, a chamada cultura popular tradicional como o lócus por excelência da diversidade cultural brasileira e as suas potencialidades indenitárias, étnicas e criativas. Esse circuito discursivo alimenta e retroalimenta o fazer criativo dos estilistas e a gestão conceitual das mercas, cujo valor simbólico e econômico (que, neste caso, não se sabe ao certo onde começa um e termina o outro) se constrói mediante esse intercâmbio entre as tradições e expressões populares, a valorização contumaz da diversidade cultural e a materialização criativa e conceitual dos estilistas, os tradutores da tradição. Esse trânsito, expresso na figura 6, instaura a marca da brasilidade Fashion e tem, por exemplo, na materialidade dos saberes e fazeres populares do artesanato uma fonte de valorização estética e política c permanente.

No design e na gastronomia tem acontecido algo muito semelhante. $\mathrm{O}$ design já está incorporado a Lei Rouanet, a partir de um parecer técnico da Fundação Nacional de Arte (FUNARTE), de 2012, reconhecendo seu estatuto artístico. De acordo com a FIRJAN, a cadeia produtiva do design abriga $117 \mathrm{mil}$ empresas, 2.717 diretamente atuando no núcleo criativo, que empregam $207 \mathrm{mil}$ profissionais (designs gráficos, criadores, desenhistas, projetistas, etc.). Em grande medida, os princípios de inovação e diversidade cultural preconizados pelo Plano da SEC/MINC se encontram inteiramente fundidos na construção do valor simbólicoeconômico do design brasileiro. O conjunto de objetos, utensílios, peças, criações e artefatos que se acham espraiados pelos escritórios, casas e ambientes públicos fornecem uma boa medida do vigor criativo do design e a sua vinculação e os usos das tradições e criações populares, presentes na arquitetura, nas criações industriais e em toda movelaria. O design brasileiro busca explorar e potencializar suas criações a partir dos fazeres e saberes populares também como forma de inovação e inserção competitiva. Não por acaso esse processo foi iniciado no anos 70, com o design gráfico Aloísio Magalhães (criador da identidade visual das principais empresas estatais e privadas brasileiras nos anos 60 e 70), idealizador e criador do Centro Nacional de Referências Culturais (CNRC, 1975), em parceria 


\section{A economia criativa no Brasil: o capitalismo cultural brasileiro contemporâneo.}

com a Universidade de Brasília (UnB) e o Ministério do Desenvolvimento, Indústria e Comércio Exterior (MDIC). O Centro Nacional de Referências Culturais deveria, de acordo com os idealizadores, integrar um acervo de informações acerca do patrimônio material e imaterial brasileiro, com vistas a criar uma identidade de objetos, artefatos, produtos, comidas, etc., que representasse e encarnassem as tradições brasileiras. Essas associações entre o design, às tradições populares e a cristalização dos bens da brasilidade (ou seja, os bens que materializam a diversidade a "autenticidade" brasileira) pode ser constada hoje mediante um exemplo-síntese.

Em abril de 2014, após diversas tentativas de entidades empresariais brasileiras, finalmente a aguardente brasileira foi reconhecida (a marca registrada) como cachaça brasileira no mercado de bebidas norte-americano (maior do mundo), suprimindo o antigo rótulo de rum brasileiro, utilizado pelos importadores e compradores para definir o gênero alcoólico brasileiro no mercado americano. Segundo os representantes da Associação Brasileira de Bebidas (ABRABE), essa conquista jurídica pode expandir o volume de exportações da bebida brasileira (atualmente de U\$ 14 milhões), pois certamente, agora, a cachaça, uma vez reconhecida como brasileira, poderá ser associada a outros elementos da brasilidade, como a música (como o samba e a Bossa Nova, muito difundidos nos EUA), a comida (principalmente a feijoada) e, sobretudo, a utilização da cachaça brasileira para feitura da caipirinha, e não mais o rum brasileiro para preparar a caipirinha. Os designs brasileiros laçam mão da chalaça e do seu imaginário, para criar rótulos, garrafas e também para deslocar o produto para outros ambientes, como decoração de escritórios, espaços de lazer e exposição, ambientes domésticos e públicos, como livrarias, centros culturais, lojas de roupas, dentre outras.

O registro da cachaça como marca brasileira dinamiza toda discussão técnica e a formulação de políticas em torno da Indicação Geográfica (IG), largamente utilizado como um protocolo de estudos técnicos e científicos com vistas à definição da territorialidade e "origem" geográfica e cultural de determinados produtos (comidas, bebidas, artesanatos, modos de fazer, etc.). As indicações Geográficas se inscrevem no âmbito de uma teia jurídico-normativa global, que, após a Rodada do Uruguai (1994), criou o arcabouço legal do Acordo Relativo aos Aspectos do Direito da Propriedade Intelectual Relacionados com o Comércio (ADPIC), também conhecido internacionalmente como acordo TRIPs. No interior desse regramento, gerenciado e disciplinado pela OMC (Organização Mundial do Comércio), está a Indicação Geográfica (IG). No Brasil, a Indicação Geográfica é certificada como uma modalidade da produção industrial, semelhante a patente e a marca. Um exemplo dessas afinidades é, por exemplo, a exportação da cachaça orgânica brasileira, cuja marca tem granjeado destaque na Europa, com a previsão de exportação de 60 mil litros para 2013, somente por parte dos produtores familiares da Agrícola Agroindústria Colônia Nova de Crissiumal, no Rio Grande 
Elder P. Maia Alves

Carlos Alexsandro de Carvalho Souza

do Sul ${ }^{24}$. Em agosto de 2012 foi realizado, em Fortaleza, no Ceará, o II Simpósio Internacional de Indicações Geográficas, cuja e o apoio contou com diversas entidades e instituições da esfera governamental brasileira, tais quais: o Banco do Nordeste (BNB); o governo do Ceará; Ministério da Agricultura, Pecuária e Abastecimento (MAPA); Conselho Nacional de Desenvolvimento Científico e Tecnológico CNPq; o Serviço Brasileiro de Apoio á Pequena e Microempresa (SEBRAE); a Coordenação de Aperfeiçoamento de Pessoal de Nível Superior (CAPES); o Instituto Nacional de Propriedade Industrial (PNPI) e a Agência Brasileira de Promoção de Exportação e Investimentos (APEX-BRASIL), ligada ao Ministério do Desenvolvimento, da Indústria e Comércio Exterior (MDIC). Não é necessário reforçar como a gastronomia está umbilicalmente inserida nesses processos, no qual, no caso do fazer gastronômico, faz do chefe dos restaurantes especializados e sofisticados os tradutores e criadores da brasilidade gastronômica, assim como s estilistas e designs estão para a brasilidade no design e a brasilidade Fashion.

\section{Considerações finais}

Como de pode depreender, é em meio ao escopo geral de expansão do consumo cultural das famílias brasileiras que se tornam inteligíveis não só os interesses e as distintas traduções da categoria de economia criativa, mas também a existência de uma miríade de propostas, discussões, projetos e leis (nova Lei Rouanet; Vale Cultura; regulamentação do uso da carteira de meio entrada, Lei 12.485, dentre outras) que impactam a dinâmica dos interesses estéticos e comerciais dos diversos agentes que animam os mercados culturais brasileiros contemporâneos. Desse modo, o processo de tradução e institucionalização do tema/conceito de economia criativa, lavado a cabo, por exemplo, pela FIRJAN e o Ministério da Cultura, tem se realizado em face da expansão do capitalismo cultural brasileiro, para o qual a categoria teórica e prática de economia criativa tem desempenhado um destacado de relevo.

${ }^{24} \mathrm{http}: / /$ www.organicsnet.com.br/2012/09/cachaca-organica-brasileira-ganha-a-europa/ 


\section{A economia criativa no Brasil: o capitalismo cultural brasileiro contemporâneo.}

\section{Referências}

LIPOVETSKY, Gilles e SERROY, Jean. A cultura mundo. São Paulo, Cia das Letras, 2011.

ALVES, Elder P. Maia. A economia simbólica da cultura popular sertanejo-nordestina. Edufal, Maceió, 2011.

(Org.) Políticas culturais para as culturas populares no Brasil contemporâneo. Edufal, Maceió, 2011.

BAUMAN, Zygmunt. Modernidade líquida. Rio de Janeiro, Jorge Zahar Editora, 2001.

BARBOSA, Lívia e CAMPBEL, Colin (ORG). Cultura, consumo e identidade. Rio de Janeiro, Fundação Getúlio Vargas, 2007.

CANCLINI, Nestor. Cultura hibridas. Edusp, São Paulo, 2005.

ELIAS, Norbert. Mozart: sociologia de um gênio. Rio de Janeiro, Jorge Zahar Editor, 1995.

FARIAS, Edson. Ócio e negócio: festas populares e entretenimento-turismo no Brasil. Editora Appris, Curitiba, 2011.

(Org.) Práticas culturais nos fluxos e redes da sociedade de consumidores.

Brasília, Verbis, 2010.

FOUCAULT, Michael. Arqueologia do saber, Rio de Janeiro, Forense, 1986.

REIS, Ana Carla Fonseca. Cidades criativas. São Paulo, SESI-SP, 2012.

SISTEMA FIRJAN. A cadeia das indústrias criativas no Brasil. Rio criativo, Rio de Janeiro, 2008.

UNCTAD, Creative Economy - Report 2008, United Nations, 2011.

\subsection{Sites consultados}

http://www.valor.com.br/

(http://www.filmeb.com.br/portal/html/graficosetabelas.php).

http://www.folha.uol.com.br/

http://www.ebc.com.br

http://info.abril.com.br/games/noticias/2013/

http://www.ancine.gov.br/

http://www.culturaemercado.com.br/ 